\title{
The links between large igneous provinces, continental break-up and environmental change: evidence reviewed from Antarctica
}

\author{
Bryan C. Storey ${ }^{1}$, Alan P. M. Vaughan ${ }^{2}$ and Teal R. Riley ${ }^{2}$ \\ ${ }^{1}$ Gateway Antarctica, Private Bag 4800, University of Canterbury, Christchurch, New Zealand. \\ ${ }^{2}$ British Antarctic Survey, High Cross, Madingley Road, Cambridge CB3 OET, England.
}

\begin{abstract}
Earth history is punctuated by events during which large volumes of predominantly mafic magmas were generated and emplaced by processes that are generally accepted as being, unrelated to 'normal' sea-floor spreading and subduction processes. These events form large igneous provinces (LIPs) which are best preserved in the Mesozoic and Cenozoic where they occur as continental and ocean basin flood basalts, giant radiating dyke swarms, volcanic rifted margins, oceanic plateaus, submarine ridges, and seamount chains. The Mesozoic history of Antarctica is no exception in that a number of different igneous provinces were emplaced during the initial break-up and continued disintegration of Gondwana, leading to the isolation of Antarctica in a polar position. The link between the emplacement of the igneous rocks and continental break-up processes remains controversial. The environmental impact of large igneous province formation on the Earth System is equally debated. Large igneous province eruptions are coeval with, and may drive environmental and climatic effects including global warming, oceanic anoxia and/or increased oceanic fertilisation, calcification crises, mass extinction and release of gas hydrates.

This review explores the links between the emplacement of large igneous provinces in Antarctica, the isolation of Antarctica from other Gondwana continents, and possibly related environmental and climatic changes during the Mesozoic and Cenozoic.
\end{abstract}

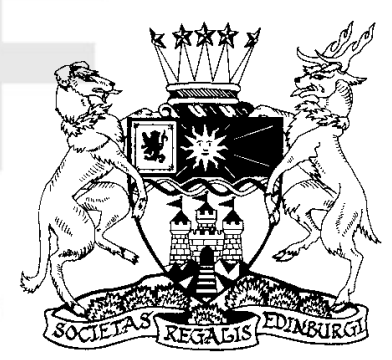

KEY WORDS: climate change, Earth System, Gondwana break-up, mafic magma, supercontinent

One of the intriguing aspects of the geological evolution of Antarctica is the large volume of intracontinental igneous rocks that were emplaced during the Mesozoic and Cenozoic. This is in marked contrast to the Palaeozoic, which was almost devoid of intracontinental igneous activity and during which time Antarctica was located almost centrally within Gondwana. The emplacement of the Mesozoic igneous provinces was contemporaneous with the gradual breakup and disintegration of Gondwana, leading eventually to the isolation of Antarctica in a south polar position. What is even more notable is that Antarctica itself continued to rift after it was isolated in its south polar position, forming the West Antarctic Rift System (Behrendt et al. 1991), with emplacement of related igneous rocks.

The link between the emplacement of the igneous rocks in Antarctica, rifting and continental breakup processes remains enigmatic (Storey 1995; Rosenbaum et al. 2008). The potential link between large igneous provinces and plate tectonic processes has been considered because many of the Mesozoic provinces were located close to once active plate boundaries and continental margins. Alternatively, the magmatic pulses responsible for producing large volumes of igneous rock in relatively short periods of time have also been related to some form of internal heating (thermal anomaly) in the Earth's mantle, due either to the insulation of the Gondwana supercontinent (e.g., Gurnis 1988; Coltice et al. 2007), or a mantlesourced thermal upwelling, i.e., mantle plume (Morgan 1971, 1981; Richards et al. 1989). Mantle plumes may either have caused the continents to rift and break up (active mantle hypothesis, Morgan 1971) or have been unroofed by chance due to plate tectonic processes causing continental break-up (passive mantle hypothesis, White \& McKenzie 1989). Although the Gondwana magmatic provinces are mainly mafic in composition, large silicic provinces also exist, part of which are present in Antarctica (Pankhurst et al. 1998).

This paper will review the connections between the emplacement of the large igneous provinces in Antarctica formed during the Mesozoic and Cenozoic and the relationship of these to the break-up of Gondwana. A central question is whether these huge manifestations of basic magmatism were associated with notable positive thermal anomalies in the subcontinental upper asthenospheric mantle (e.g., Richards et al. 1989; White \& McKenzie 1989; Johnston \& Thorkelson 2000; Thompson \& Gibson 2000; Coltice et al. 2007) or whether they formed by decompression melting related to plate tectonic processes (e.g., King \& Anderson 1995; Anderson 2000, 2005; Elkins-Tanton 2005; Foulger 2007). For this reason, petrogenetic models for the formation of the igneous provinces are reviewed. The paper will also consider the impact of the formation of the igneous provinces on the Earth System in general. Large igneous province eruptions are implicated in environmental and climatic changes including global warming, oceanic anoxia and/or increased oceanic fertilisation, calcification crises, mass extinction and potentially the release of gas hydrates (Hesselbo et al. 2000; Wignall 2001; Wignall et al. 2005). Although the volume of igneous rocks emplaced during the Mesozoic and Cenozoic evolution of Antarctica may not, in some cases, strictly be of sufficient volume for them to be classified as large igneous 


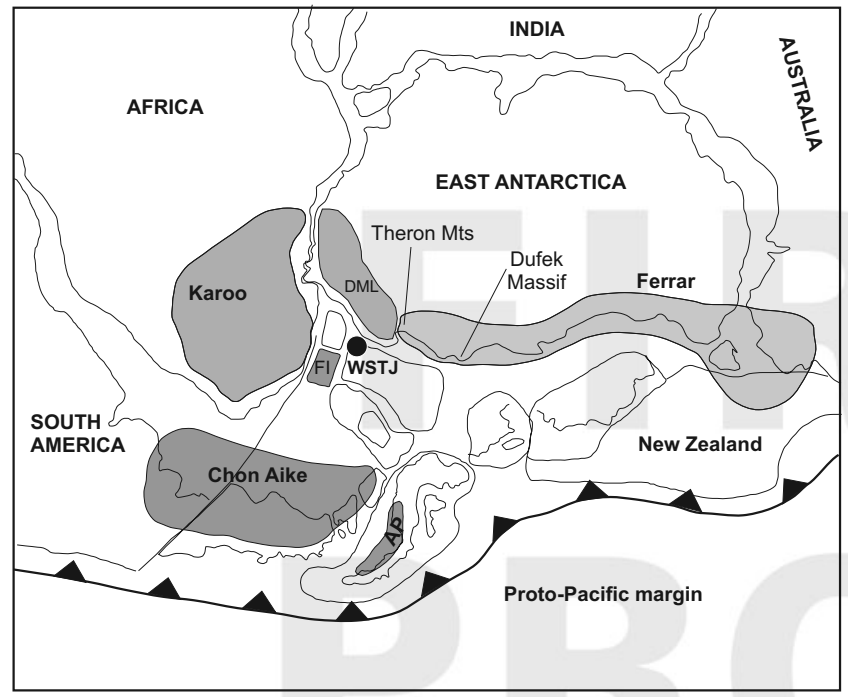

Figure 1 Middle Jurassic Gondwana reconstruction showing three large igneous provinces, Ferrar, Karoo and Chon Aike (after Storey \& Kyle 1997), and the location of the Weddell Sea Triple Junction (WSTJ) after Elliot \& Fleming 2000. Abbreviations: $\mathrm{AP}=\mathbf{\| l}$; $\mathrm{DML}=$ Dronning Maud Land; FI $=$ Falkland Islands.

provinces (LIPs), nevertheless they are included here as they are clearly related to Gondwana rifting and subsequent breakup. We first present details of the Antarctic igneous provinces, including their petrogenesis, and then consider their links to continental break up processes. Central to the debate concerning the origin of any large igneous province is establishing whether a mantle plume source existed and determining whether the role of the plume was restricted to conductive heat transfer to the lithosphere, or whether uncontaminated plume-derived magmas were erupted at the surface or intruded at upper crustal levels.

\section{Antarctic intracontinental igneous provinces}

\subsection{Ferrar magmatic province}

The Middle Jurassic (180.3 $\pm 2 \cdot 2 \mathrm{Ma}$; Heimann et al. 1994) Ferrar magmatic province in Antarctica is predominantly a mafic sill complex, but includes flood basalts (Elliot et al. 1999), phreatomagmatic volcanic rocks (Elliot \& Hanson 2001), mafic dykes (Fleming et al. 1992; Leat et al. 2000) and layered mafic intrusions (Storey \& Kyle 1997). It has a linear outcrop and extends $3500 \mathrm{~km}$ from the Theron Mountains of Antarctica to southeast Australia (Fig. 1) (Elliot \& Fleming 2004). Its linear outcrop pattern is unusual among LIPs, but the extent to which the elongate outcrop is a function of icecover limiting the outcrop is uncertain (Leat 2008) and there is geophysical evidence indicating a greater extent of Ferrar province rocks under the East Antarctic Ice Sheet (Ferraccioli et al. 2001). Its main outcrops are in Antarctica (Kyle 1980; Kyle et al. 1981), but it also occurs in southeast Australia, (Hergt et al. 1989a) New Zealand (Mortimer et al. 1995), and South Africa (Riley et al. 2006). The total volume of lava and intrusions in the Ferrar Province is estimated to be around $200,000 \mathrm{~km}^{3}$, allowing $60,000 \mathrm{~km}^{3}$ for the Dufek-Forrestal intrusions, $125,000 \mathrm{~km}^{3}$ for sills, lavas and dykes in Antarctica, and $15,000 \mathrm{~km}^{3}$ for sills in Tasmania (Hergt et al. 1989a; Elliot \& Fleming 2000). This is a considerable reduction from early estimates of $500,000 \mathrm{~km}^{3}$ (e.g. Kyle et al. 1981), following a reinterpretation of the extent of the Dufek and Forrestal intrusions based on aeromagnetic surveys (Ferris et al. 1998).

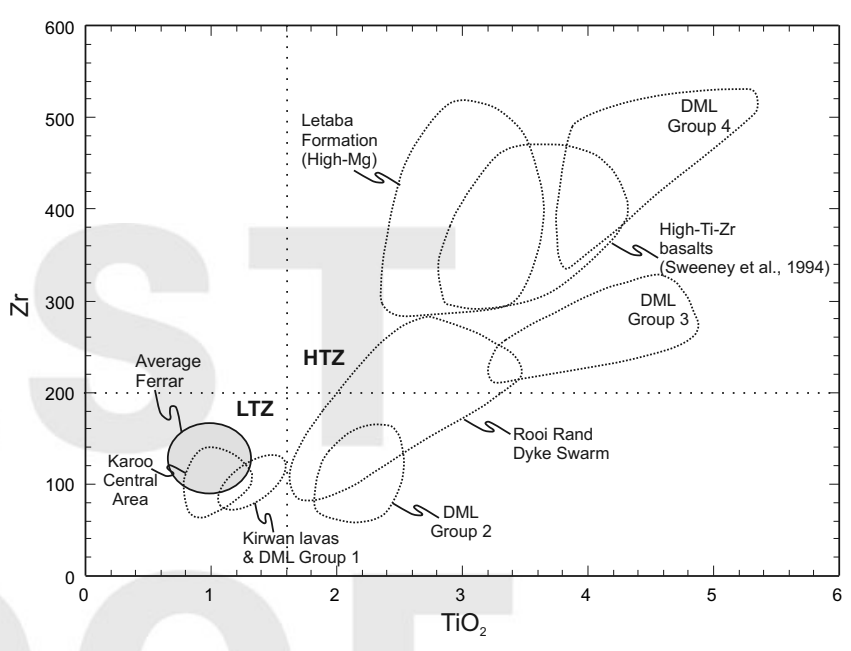

Figure 2 Variation in $\mathrm{Zr}$ vs $\mathrm{TiO}_{2}$ for dyke and lava compositions from the Karoo (Kirwan lavas, Karoo central area, Rooi Rand dyke swarm, Letaba Formation, Lebombo high Ti-Zr basalts) and Dronning Maud Land provinces (DML groups 1-4) and average Ferrar compositions. Data sources in Riley et al. (2006). Abbreviations: HTZ = high Ti zone; LTZ = low Ti zone.

As a result of detailed ${ }^{40} \mathrm{Ar} /{ }^{39} \mathrm{Ar}$ and $\mathrm{U}-\mathrm{Pb}$ geochronology, the synchronicity of the Ferrar and Karoo province in southern Africa has long been recognised (e.g. Encarnación et al. 1996; Pálfy \& Smith 2000; Riley \& Knight 2001), although the peak (based on a compilation of age dates) of Karoo magmatism at $183 \pm 2 \mathrm{Ma}$ is $3 \mathrm{Myr}$ older than the Ferrar peak of $180 \cdot 3 \pm 2 \cdot 2$ Ma. Although closely spaced in time, the rocks of the Ferrar and the Karoo volcanic provinces are markedly different in their geochemistry. The basalts of the Ferrar province are entirely of low- $\mathrm{Ti}-\mathrm{Zr}$ type and are typically high $\mathrm{SiO}_{2}$ compared to the once neighbouring Karoo province (Fig. 2). Other key features of the Ferrar Province are $\mathrm{Sr}$ and $\mathrm{Nd}$ isotope ratios, with Ferrar basalts having initial $\left({ }^{87} \mathrm{Sr} /{ }^{86} \mathrm{Sr}\right)_{180}$ ratios in the range $0.708-0.711$, and $\varepsilon \mathrm{Nd}_{180}$ values in the range -2 to -8 (Fig. 3). These isotopic characteristics of the erupted rocks of the Ferrar province, coupled with the high $\mathrm{SiO}_{2}(50-52$ $\mathrm{wt} \%$ ) and high concentrations of the large ion lithophile elements, have led several workers (e.g. Antonini et al. 1999) to suggest that processes involving contamination of the magmas by continental crust was important, whilst other workers (e.g. Kyle 1980; Hergt 2000) maintain that the continental crust was not involved in the petrogenesis of Ferrar magmas. Molzahn et al. (1996) suggested that their 'mantle-like' Os isotope ratios and their radiogenic ${ }^{87} \mathrm{Sr} /{ }^{86} \mathrm{Sr}$ are characteristics of their mantle source.

The linear outcrop pattern of the Ferrar magmatic province, sub-parallel to the proto-Pacific margin of Gondwana (Fig. 1), has led some workers (e.g. Hergt et al. 1991) to attribute the chemistry of the Ferrar magmas to enrichment of their mantle source material by subduction-derived fluids. For the most part, the outcrop pattern follows the subduction related CambroOrdovician Ross Orogen and is sub-parallel to the active Mesozoic continental margin, although geophysical data (Ferraccioli et al. 2001) provides evidence for Ferrar magmatic rocks more than $500 \mathrm{~km}$ from the margin, beneath the Wilkes Subglacial Basin (Fig. 4), making a subduction-related origin less likely. Cox (1988), however, attributed the linear outcrop pattern to a similar-shaped heat source that he referred to as a "hot line". Elliot et al. (1999) and Storey \& Kyle (1997) suggested the Ferrar magmas originated from a single magmatic centre and that the present-day outcrop is the result of long distance magma transport from this point source in sills or 


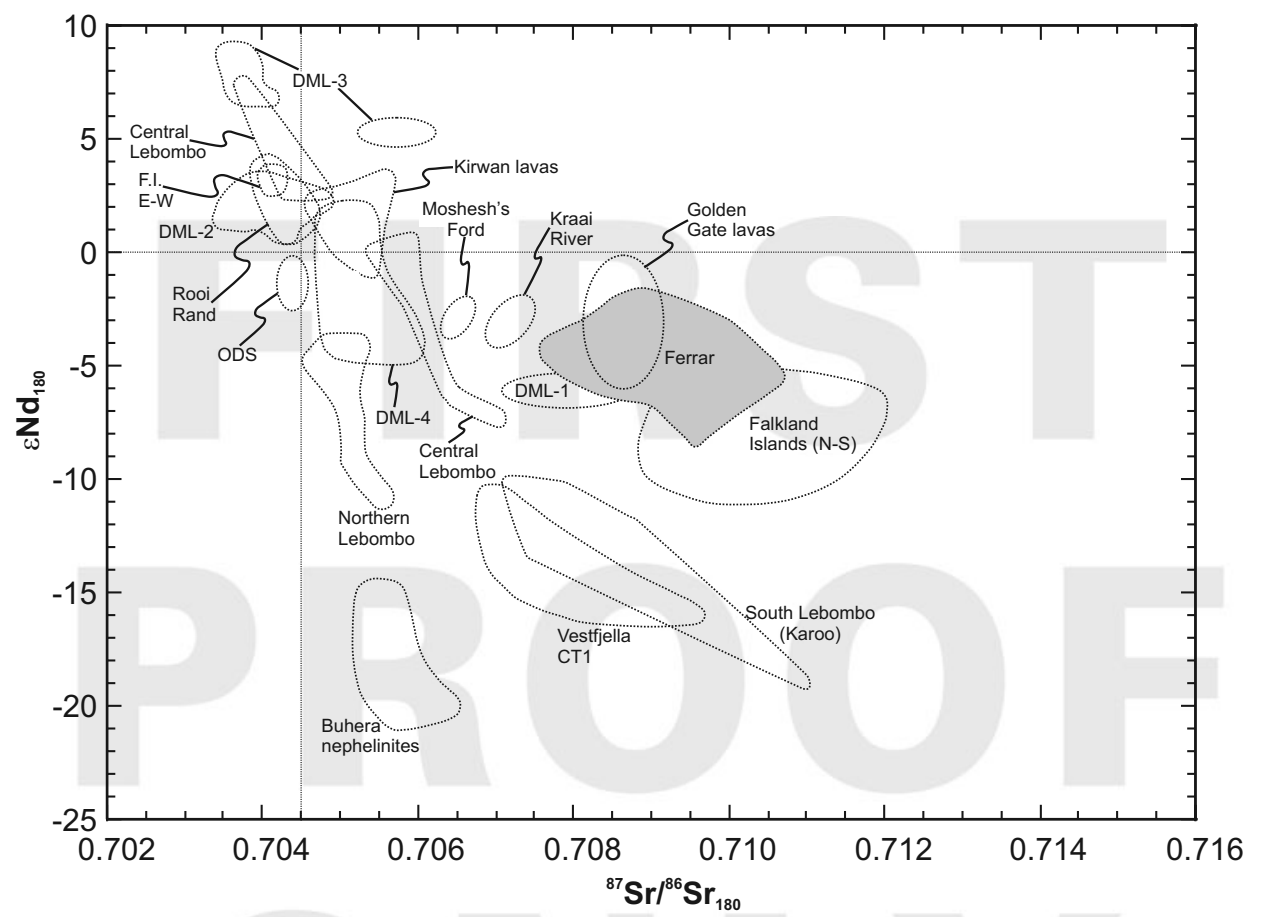

Figure 3 Initial $\delta \mathrm{Nd}$ and ${ }_{87} \mathrm{Sr} /{ }_{86} \mathrm{Sr}$ for intrusive rocks and lavas from the Karoo and Ferrar magmatic provinces. All data sources are available in Riley et al. 2006. All data are normalised to an initial value at $180 \mathrm{Ma}$. Abbreviations: F.I. = Falkland Islands; ODS $=$ Okavango dyke swarm.

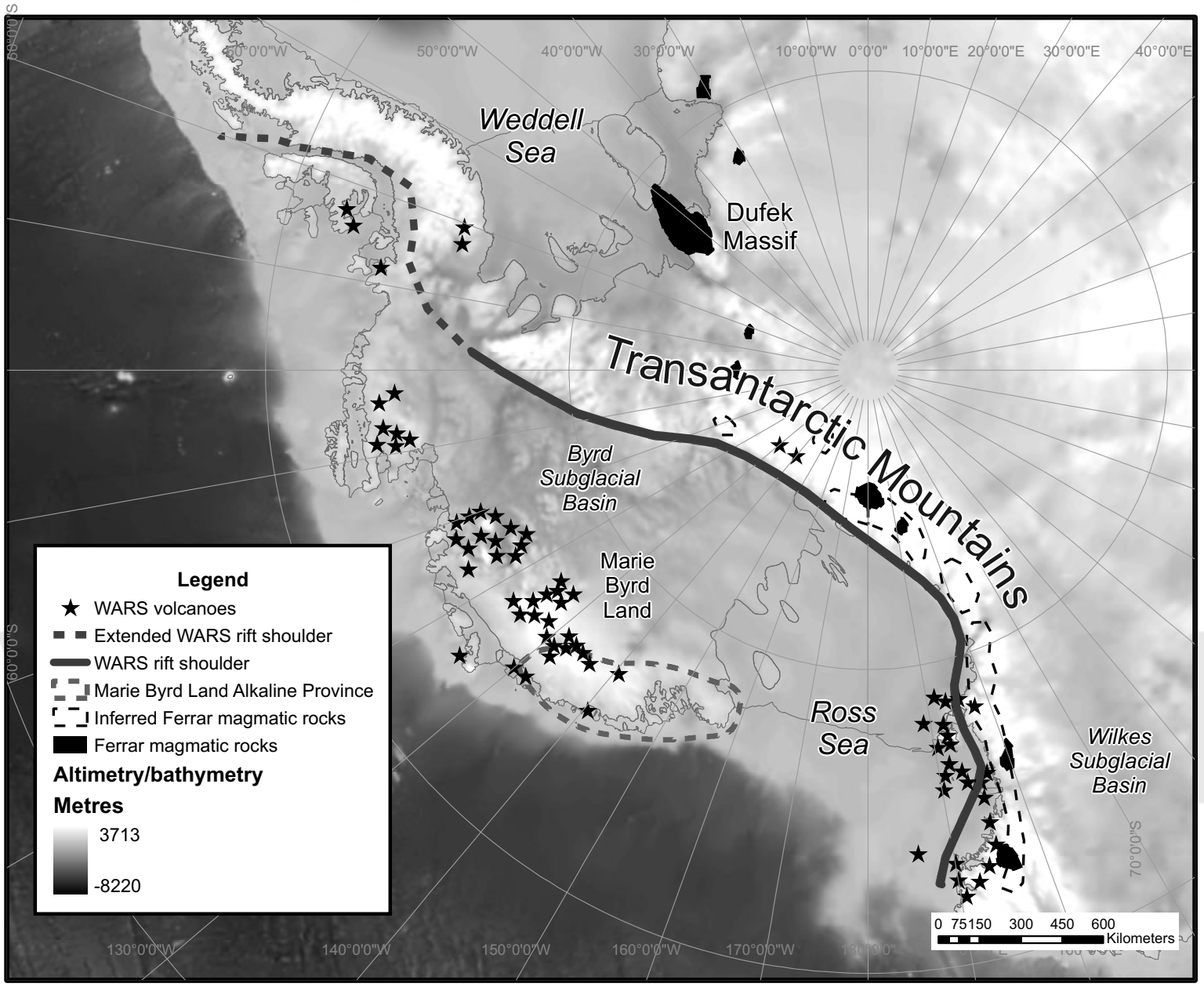

Figure 4 Antarctic map showing the Transantarctic Mountains as the rift shoulder of the West Antarctic Rift System (WARS), the related Cenozoic alkaline magmatic province (WARS volcanoes), the outline of the Middle Jurassic Ferrar magmatic province and the outline of the mid Cretaceous alkaline magmatism in Marie Byrd Land. 
dykes. Elliot \& Fleming (2004) suggested that magma transport was ultimately controlled by an active rift system initiated in the Early Jurassic, and that the point source for the magmas was a thermal anomaly (mantle plume) at the Weddell Sea triple junction (Fig. 1) (Elliot \& Fleming 2000), which was also adjudged to be responsible for the Karoo low-Ti basalts of southern Africa.

\subsection{Dronning Maud Land province}

Magmatic rocks of the geochemically distinct Karoo magmatic province of Southern Africa are found in the once neighbouring western Dronning Maud Land sector of Antarctica (Fig. 1). Although for the most part geographically separate, Brewer et al. (1992) identified both Karoo- and Ferrar-like rocks in the Theron Mountains of Coats Land, Antarctica (Fig. 1). In western Dronning Maud Land, Karoo magmatic activity appears to have been less intense. Flood basalt lava sequences are thinner $(<1 \mathrm{~km}$ thickness; Luttinen \& Furnes 2000) than their southern African equivalents, which are at least $1600 \mathrm{~m}$ in Lesotho (Marsh \& Eales 1984). Mafic dyke suites are also on a much smaller scale, with widths typically $<2 \mathrm{~m}$ (Riley et al. 2005). The geochemistry of the Karoo igneous rocks has been interpreted to indicate derivation from an enriched lithospheric mantle source (e.g. Erlank 1984) with or without crustal contamination. Others have proposed that the Karoo magmas were partial melts of a mantle plume source that were subsequently contaminated by lithospheric mantle components (Cox 1992; Ellam et al. 1992; Sweeney et al. 1994).

The presence of ferropicrite and picrite dykes, together with other geochemical and isotopic evidence, indicates that the magmas comprising many of the Dronning Maud Land dykes were formed at depth (at least garnet lherzolite stability) as a result of anomalously high temperatures $\left(>1500^{\circ} \mathrm{C}\right)$, indicative of mantle plume derivation (Riley et al. 2005). Although ferropicrites may not represent a volumetrically significant magma type, the ocean island basalt (OIB)-like geochemistry and the inferred high temperatures of the ferropicritic primary melts (e.g. Gibson et al. 2000; Heinonen \& Luttinen 2008, 2010) strongly suggest a plume source for the Karoo LIP (cf. Riley et al. 2005), and contribute to the debate on the nature of hotspots and the existence of mantle plumes and their significance as sources of LIP magmatism (e.g. Foulger et al. 2005). Strongly depleted magma types are also a key component of the early Karoo intrusive (Riley et al. 2005; Heinonen et al. 2010). Such mid-ocean ridge basalt (MORB)-like compositions $\left({ }^{87} \mathrm{Sr} /{ }^{86} \mathrm{Sr}: 0.7035, \varepsilon \mathrm{Nd}\right.$ : -8 ; Fig. 3 ) have been recognised from several other LIPs (e.g. Siberian Traps, Wooden et al. 1993; Etendeka Province, Gibson et al. 2000) and are considered to be a key component of mantle plumes (e.g. Kerr et al. 1995). Heinonen et al. (2010) suggest their findings are more concordant with a model (Coltice et al. 2009) that suggests the generation of the Karoo magmas in an extensive melting episode caused by internal heating of the upper mantle beneath the Gondwana supercontinent. On the other hand, anisotropy of magnetic susceptibility measurements indicates the presence of a regional scale radial stress system in western Dronning Maud Land, supporting a mantle plume origin for the Karoo large igneous province (Curtis et al. 2008) and Heron \& Lowman (2011) suggest that internal heating models are not feasible.

\subsection{Jurassic silicic province of Patagonia and Antarctic Peninsula}

The recognition of silicic large igneous provinces in the geological record (e.g. the Etendeka-Parana (Bryan et al. 2010)) has led to the reassessment of many continental margin volcanic provinces worldwide (Bryan et al. 2002). The Chon Aike province (Fig. 1) of Patagonia extends from the Atlantic Coast to the Chilean side of the Andes (Pankhurst et al. 1998) and is correlated with the Jurassic silicic volcanic rocks of the Antarctic Peninsula (Riley \& Leat 1999; Riley et al. 2010). In eastern Patagonia, the volcanic rocks are predominantly flat lying and undeformed where they overlie crystalline basement rocks of Precambrian to earliest Jurassic age and Lower Jurassic, riftrelated sedimentary rocks. In contrast, silicic volcanic rocks of the Andean Cordillera form relatively narrow outcrops, which are locally deformed, tilted and strongly affected by hydrothermal alteration. The province is dominated by phenocryst-poor ignimbrites, derived from multiple caldera centers (e.g. Aragón et al. 1996; Riley \& Leat 1999), and vary in degree of welding from high grade rheomorphic ignimbrites with parataxitic textures, to the volumetrically dominant, non-welded, lithic-rich ignimbrites. Volumetrically minor rhyolite lavas, air fall, debris flow, and epiclastic deposits also occur.

The province is geochemically bimodal, but is dominated by rhyolite, with only rare examples of intermediate (basaltic andesite and/or andesite) compositions (Riley et al. 2003a). The eruptive ages of silicic volcanic rocks from Patagonia and the Antarctic Peninsula defined by $\mathrm{U}-\mathrm{Pb}$ ion microprobe dating (Pankhurst et al. 2000) and ${ }^{40} \mathrm{Ar} /{ }^{39} \mathrm{Ar}$ geochronology (Féraud et al. 1999; Pankhurst et al. 2000) indicate that volcanism continued for as long as $30 \mathrm{Myr}$, from the Early Jurassic to Late Jurassic, but occurred in three main phases. The first phase of volcanism (188-178 Ma; V1 of Pankhurst et al. 2000) has a peak eruptive age of $184 \pm 2 \mathrm{Ma}$, and brackets the peak of flood basalt volcanism of the Karoo and Ferrar provinces at $183 \pm 1 \mathrm{Ma}$ (e.g. Encarnación et al. 1996). Volcanic rocks of the V1 group occur in the eastern part of the region (Marifil Formation) and at the southern Antarctic Peninsula (Mt Poster Formation, Rowley et al. 1982; Brenneke Formation, Wever \& Storey 1992). The V2 episode crops out in the central and western parts of the Chon Aike Province and widely across the north eastern Antarctic Peninsula (Mapple Formation, Riley \& Leat 1999; Riley et al. 2010). V2 has a peak eruptive age of $169 \pm 2 \mathrm{Ma}$ (Pankhurst et al. 2000). The Tobífera Formation of southernmost Patagonia, however, yielded ages of 178 and $171 \mathrm{Ma}$ (Pankhurst et al. 2000) and may partly span the interval between V1 and V2 (172-162 Ma). The final episode, V3 (157-153 Ma), is confined to the Andean volcanic outcrops of Argentina and Chile, although small granite bodies of this age occur both in western Patagonia and in the western Antarctic Peninsula, and maybe sub-volcanic equivalents.

The three eruptive phases define an age progression of magmatism from an intraplate to continental margin setting, away from the locus of flood basalt volcanism in the Karoo province (Pankhurst et al. 2000). Concomitant with the age progression is a change in rhyolite composition from intraplate (higher $\mathrm{Nb}$, $\mathrm{Y}$; V1, Early Jurassic) to calc-alkaline (lower Nb, Y; V2 and V3, Middle to Late Jurassic) geochemical signatures (Fig. 5). The Early Jurassic rocks (V1) are interpreted as the partial melts of hydrous mafic crust that have mixed with fractionated components and homogenised following long term storage. The stronger within-plate signature in the V1 rocks is a result of their location distal to the continental margin, whereas the V2 and V3 rocks are closer to the Pacific margin. The Middle Jurassic silicic volcanic rocks of the Mapple Formation (Antarctic Peninsula) and those of the Chon Aike Formation (South America) are also thought to have been generated as a result of anatexis of Grenvillian age hydrous mafic lower crust of andesitic composition, linked to pre-Middle Jurassic subduction, and superimposed fractional crystallisation (Pankhurst 


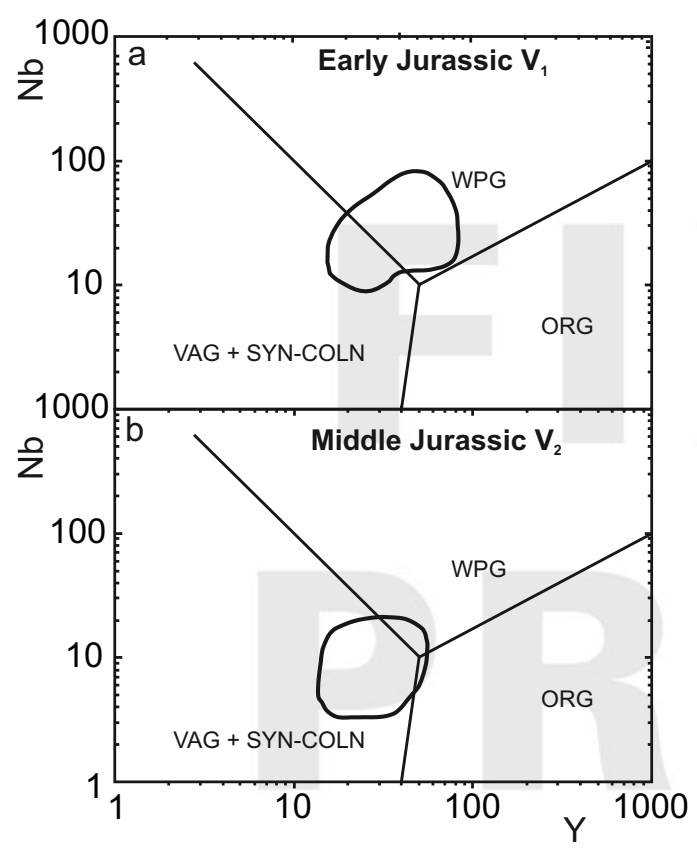

Figure $5 \mathrm{Nb}-\mathrm{Y}$ discrimination plots for silicic rocks from the Antarctic Peninsula and Patagonia. The fields characteristic of within-plate granites (WPG), ocean ridge granites (ORG), and volcanic arc/syncollisional granites $(\mathrm{VAG}+\mathrm{SYN}-\mathrm{COLN})$ are those defined by Pearce et al. 1984.

\& Rapela 1995; Riley et al. 2001), but have much stronger subduction-modified trace element abundances (low Nb, Low Y).

A Middle Jurassic $(173 \pm 3 \mathrm{Ma})$ intracontinental granitic suite was identified within West Antarctica by Storey et al. (1988), varying in composition from A-type granites to crustal melts. The A-type granites were modelled as having being derived by closed system differentiation of a Ferrar mafic magma with varied degrees of crustal contamination. They may represent plutonic equivalents of the silicic volcanic rocks of the Chon Aike province (V2).

The fundamental reason that a large silicic province formed in southern South America, in contrast to the synchronous mafic provinces in the interior of Gondwana, was due to the presence of a fertile crustal source close to the continental margin (Bryan et al. 2002). Large degrees of crustal partial melting, essential to produce the large volumes of rhyolitic magma, are controlled by the water content and composition of the crust and the large thermal input from the mantle. Although the thermal budget for mafic and silicic large igneous provinces is considered the same (i.e. a large thermal input), hydrous crustal material is more receptive to melting, and will begin to melt at lower temperatures (Bryan et al. 2002). Ancient and active convergent margins tend to be characterised by a fertile, hydrous lower crust that can readily melt. Longlived subduction promotes the development of a hydrated lower crust and lithospheric mantle that can extend for several hundred kilometres from the active margin (e.g., Karoo, western United States; Fitton et al. 1988; Davis et al. 1993), particularly if significant lateral accretion has occurred over time. The silicic melts can also act as a density barrier, preventing the mafic magmas from reaching the surface (cf. Huppert \& Sparks 1988), as will a lack of deep, crust-penetrating structures that can transfer mafic magma to the surface.

\subsection{Mid-Cretaceous alkali magmatism}

Mid-Cretaceous igneous rocks of central Marie Byrd Land (Fig. 4) in Antarctica, and on the formerly neighbouring Campbell Plateau, record a rapid change from subduction- related to rift-related magmatism (Weaver et al. 1994). This correlates with the final stages of subduction of the Phoenix plate and the subsequent rifting of New Zealand from West Antarctica prior to opening of the Southern Ocean. The subduction-related igneous suite is calc-alkalic I-type diorites, granodiorites and monzogranites (108-124 Ma). Rift magmatism produced diverse A-type granitoids (monzonites, syenites, syenogranites, and alkali feldspar granites; $95 \mathrm{Ma}$ to $102 \mathrm{Ma}$ ) and mafic plutons, dykes and sills $(107 \pm 5 \mathrm{Ma})$ of continental flood basalt affinity. The mafic dyke suites have been modelled by mixing between tholeiitic asthenosphere-derived OIB with a HIMU composition and alkaline lithospheric mantle derived alkaline magmas (Storey et al. 1999). It has been suggested that rifting was caused by changes in plate boundary forces; however, Weaver et al. (1994) have suggested that mantle plume activity may have begun in mid-Cretaceous time, triggering melting of the lithosphere and controlling the locus of rifting. A mantle plume hypothesis is supported by evidence of $0 \cdot 5-1 \cdot 2 \mathrm{~km}$ excess topographic elevation for West Antarctica and adjacent sea floor, and by evidence of anomalously high subsidence rates on Campbell Plateau in the Palaeogene as it and New Zealand rifted away from a zone of mantle upwelling on the West Antarctic margin (Sutherland et al. 2010).

\subsection{Cenozoic alkali magmatic province}

A belt of Cenozoic alkaline magmatic rocks (48 Ma to presently active) lies within a broad region of extended crust known as the West Antarctic Rift System (WARS) (Fig. 4; LeMasurier 1990; Behrendt et al. 1991). The Cenozoic extension is characterised by thin-crust approximately $20-30 \mathrm{~km}$-thick, deep-rift basins within the Ross Sea region and Marie Byrd Land (Behrendt et al. 1991) and significant uplift along the $3500 \mathrm{~km}-$ long, $4500 \mathrm{~m}$ high Transantarctic Mountain front which separates the rift from the East Antarctic shield (ten Brink et al. 1993). The West Antarctic Rift System is marked by a topographic trough 750-1000 km wide and $3000 \mathrm{~km}$ long, running from near the Ellsworth-Whitmore Mountains to the Ross Embaymentnorthern Victoria Land (Fig. 4) (LeMasurier \& Thomson 1990; Behrendt et al. 1991, 1992). The WARS is similar in size to the East African rift system and to the Basin and Range province of the western United States (Tessensohn \& Wörner 1991) and is geometrically asymmetric. The eastern flank in Marie Byrd Land is characterised by basin-and-range style of topography, with about $3 \mathrm{~km}$ of uplift in the central part (LeMasurier \& Rex 1989). The opposite flank in northern Victoria Land (NVL) consists of the Transantarctic Mountains, the uplifted roots of the early Paleozoic Ross Orogen (Stump 1995).

Eighteen major alkaline volcanoes and many smaller centres are found within the Marie Byrd Land province (Fig. 4). The volcanoes are large, mostly $3000 \mathrm{~m}$ in height, and are composed predominantly of felsic alkaline lavas, phonolite, trachyte, rhyolite and intermediate differentiates. Smaller basaltic centres composed of alkali basalt, basanite and hawaiite are also present and are common as parasitic vents and basal flows at the larger volcanoes. The majority of the large composite volcanoes in Marie Byrd Land are found in linear chains that become progressively younger towards the perimeter of the province. The pattern of volcanism has been explained by the sequential release of magmas from shallow chambers along a propagating relict fracture system reactivated during Cenozoic extension (LeMasurier \& Rex 1989; Panter et al. 1994). In Northern Victoria Land, Cenozoic bimodal plutons with gabbroic and syenitic portions, and alkali basalt-basanite-tephrite dykes are some of oldest parts of the province, dating back to 48 Ma (Rocchi et al. 2002). Large volcanic edifices, present in the McMurdo Sound region near Ross Island, are basaltic shield 
volcanoes, strato-volcanoes with dominant trachytic and phonolitic compositions, and small, isolated basaltic scoria cones and lava flows.

The alkaline basalts have similar trace-element concentrations and isotope ratios that approach the HIMU compositions of oceanic islands (Hofmann 1997). The origin of the extreme HIMU signature has been attributed to recycling of ancient oceanic crust within plumes rising from the deep mantle (Hofmann \& White 1982; Hart et al. 1992). Geochemical studies of basalts from the West Antarctic rift support plume-related sources for volcanism (Hart et al. 1995, 1997; Rocholl et al.1995). Plume models have also been used to explain tectonic doming and the spatial pattern of volcanic centres within the Marie Byrd Land province (LeMasurier \& Rex 1989; Hole \& LeMasurier 1994; LeMasurier \& Landis 1996). Some models appeal to a single young 'active' plume concurrent with the onset of volcanism 28-35 Ma ago (Kyle et al. 1994; LeMasurier \& Landis 1996), while others favour a passive model involving a "fossilised" plume head fixed at the base of the lithosphere (Rocholl et al. 1995; Hart et al. 1997). In the fossil plume model, the arrival of a plume head prior to the mid-Cretaceous breakup of New Zealand from Antarctica may explain the extremely broad distribution (over $5000 \mathrm{~km}$ ) and significant age-span (100 Ma) of HIMU-type alkaline volcanism found throughout the continental borderlands of the southwest Pacific (Lanyon et al. 1993; Hart et al. 1997; Panter et al. 1997). Magmatism associated with either Jurassic; 184 Ma (Encarnación et al. 1996) or Cretaceous; 100 Myr (Weaver et al. 1994) rifting events may signal early plume-lithosphere interaction. Seismic tomography (Spasojevic et al. 2010) and subsidence data (Sutherland et al. 2010) support evidence for a very longlived deep mantle thermal anomaly off West Antarctica, probably triggered by cessation of subduction along the Gondwana margin.

Panter et al. (2000) proposed a variant on the fossil plume model; one that calls upon a Cretaceous plume composed solely of the HIMU component overlain by a much more extensive pre-existing metasomatised layer within the Gondwana lithosphere. The plume-driven metasomatism may have been related to the Jurassic Bouvet-plume having enriched the Gondwana lithosphere in highly incompatible trace-elements. The plume-modified lithosphere was then underplated by a smaller HIMU-plume in mid-Cretaceous times. A Cretaceous plume-head with a diameter of $600-800 \mathrm{~km}$ would encompass these HIMU localities prior to continental breakup. Extension and rifting of New Zealand from Antarctica would have lead to adiabatic decompression melting of the fossil plume and overlying plume-modified lithosphere within widely dispersed fragments of the former Gondwanaland supercontinent.

Finn et al. (2005) reviewed the different tectonic models and concluded that the diffuse alkaline magmatic province in the south west Pacific, of which the Antarctic Cenozoic alkaline province is a part, was formed by sudden detachment and sinking of subducted slabs in the late Cretaceous that induced instabilities along the former Gondwana margin that in turn triggered lateral and vertical flow of warm Pacific mantle. According to Finn et al. (2005) the combination of metasomatised lithosphere underlain by mantle at slightly elevated temperatures was key to generating Cenozoic magmatism.

Alternative interpretations to both plume-driven and passive rifting have been proposed by Rocchi et al. (2002, 2003, 2005), which suggest that magma genesis and emplacement is due to the reactivation of pre-existing NW-SE translithospheric faults (Salvini et al. 1997), which promoted local decompression melting of an enriched mantle previously veined during a Late Cretaceous amagmatic extensional rift phase.

\section{Links to continental break-up mechanisms}

Having summarised the main features and petrogenesis of the large igneous provinces, the next section reviews the tectonic processes that may have contributed to Gondwana breakup and formation of the igneous provinces.

\subsection{Plate margin processes}

The parallelism of the current exposure of the Ferrar province to the active margin of Gondwana and to the Permo-Triassic Gondwanian fold belt has inevitably drawn attention to the role of plate margin processes in the initial mid Jurassic breakup of Gondwana (Storey 1995), as has their broad calc alkaline geochemistry (Hergt et al. 1989b). Gondwana may have been pulled apart by plate boundary processes operating on either side of the supercontinent to form back arc basins and rift zones akin to the formation the Rocas Verdes in late Jurassic times (Dalziel et al. 1974), although recent modelling suggests that this process is complex and many aspects of it are not well understood (Mikhailov et al. 2010; Siddoway 2010; Ghosh \& Holt 2012). A similar plate margin model can also be used to explain the mid-Cretaceous alkaline province in Marie Byrd Land. Marine geophysical studies have shown that approaching spreading ridges stalled close to the active margin, causing the potential transfer of Marie Byrd Land to the Pacific plate and back arc rifting (Luyendyk 1995).

\subsection{Thermal anomaly/mantle plume/hotspot}

In 1963, Wilson (1963) first suggested that the Hawaiian Islands were produced by oceanic lithosphere moving over a stationary "hot spot" in the mantle, and in 1971 Morgan (1971) suggested that lower mantle plumes exist in the Earth's mantle and may play an important role in convection and continental break-up. However, there has been considerable debate recently about the existence of lower mantle plumes (Foulger et al. 2005), with a variety of thermal plumes (King \& Ritsema 2000; Davies \& Bunge 2006; Wilson \& Dowes 2006) having been described as focused vertical upwellings that are not directly rooted in the lower mantle, as predicted by the original hotspot model (Morgan 1971). Moreover, high-resolution seismological images have shown many apparent small-scale convective heterogeneities in the uppermost mantle at margins such as the western US (e.g. Sigloch et al. 2008; West et al. 2009) and the Mediterranean (Faccenna \& Becker 2010). Subcontinental small-scale convection may be initiated by sharp temperature gradients at a craton's edge, where decompression melting may cause volcanism (King \& Anderson 1995). An indirect connection to slab return flow, which may interact with a hydrated layer in the transition zone to facilitate localised upwellings along active plate margins, has also been suggested (Leahy \& Bercovici 2007; Faccenna et al. 2010; Rey \& Mueller 2010).

However, in addition to indications from geoid anomalies, the presence of long-lived thermal anomalies in the mantle has been demonstrated by seismic velocity distribution models based on tomographic techniques using both P- and S-waves (e.g. van der Hilst et al. 1997; Montelli et al. 2004; 2006; Steinberger \& Torsvik 2012). Large, low-velocity seismic anomalies have been detected in the Earth's lower mantle at the coremantle boundary beneath Africa and the Pacific Ocean, with the chemically distinct sub-Pacific and sub-African large low shear velocity provinces (LLSVPs) becoming a robust feature (Fig. 6) (Wang \& Wen 2004; Steinberger \& Torsvik 2012). Density heterogeneities, imaged using seismic tomography, contain information about time-dependent mantle flow and mantle structure that existed in the past (Torsvik et al. 2008). During the Mesozoic, an associated modelled topographic high is situated near Gondwana rifting, raising the possibility that this 


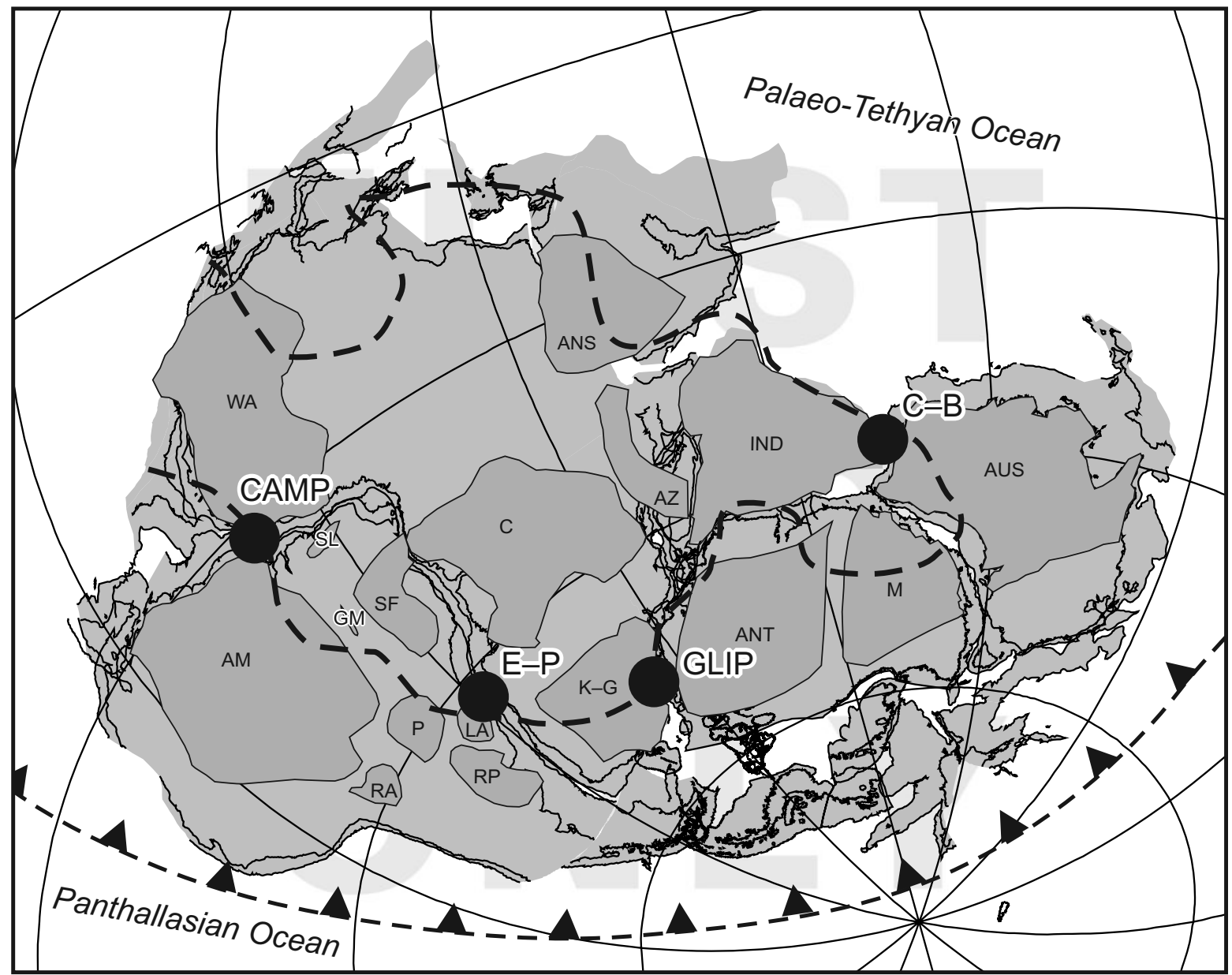

Figure 6 Gondwana reconstruction for 180 Ma (modified after Pankhurst \& Vaughan 2009) showing major cratons and projected outline of the African LLSVP (heavy dashed line) from Torsvik et al. 2010. Major postPermian large igneous province centres associated with the break-up of Gondwana are marked: CAMP $=\mathrm{Central}$ Atlantic Magmatic Province, 200 Ma (after Marzoli et al. 1999); GLIP = Gondwana Large Igneous Province, $180 \mathrm{Ma}$ (after Storey \& Kyle 1997); C-B = Comei-Bunbury LIP, 134 Ma (after Zhu et al. 2009); E-P = EtendekaParaná, 132 Ma (after Peate 1997). Craton labels are after Pankhurst \& Vaughan 2009, as follows: AM = Amazonia; ANS = Arabian-Nubian Shield; ANT = Antarctica; AUS = Australian cratons; AZ = Azania; C = Congo; $\mathrm{GM}=$ Goias Massif; IND = Indian cratons; $\mathrm{K}-\mathrm{G}=$ Kalahari-Grunehogna; $\mathrm{LA}=$ Luis Alves; $\mathrm{M}=\mathrm{Mawson}$; $\mathrm{P}=$ Paraná; $\mathrm{RA}=$ Rio Apa; $\mathrm{RP}=$ Rio de la Plata; $\mathrm{SF}=$ Sao Francisco; $\mathrm{SL}=$ San Luis; WA = West Africa.

buoyant structure may have been involved with Gondwana breakup (Conrad \& Gurnis 2003). Burke et al. (2008) have shown that LIP eruption sites of the past 300 m.y. lie vertically above the horizontal edges of the African and Pacific LLSVPs at the core-mantle boundary, and this spatial association is demonstrated for Gondwana break-up LIPs in Figure 6. Near the core-mantle boundary, the association of the high temperature of the outer core with an inclined thermal boundary layer at the margins of LLSVPs facilitates the generation of mantle plumes in the plume generation zones (Tronnes 2010). Seismic tomography studies associated with examination of large low shear velocity provinces also indicate that whole mantle convection is occurring beneath the Pacific Ocean (Schmerr et al. 2010; Liu et al. 2011), making non-plume models significantly less tenable.

Ideas vary on the role of mantle plumes in continental breakup, from the original active mantle hypothesis of Morgan (1971, 1981), who considered that plumes drive the plates and initiate continental breakup by doming and cracking the continents and pushing the continents apart, to passive models, where the plume plays no part in breakup except that the chance unroofing of a pre-existing or incubating plume results in rapid outpouring of flood basalt provinces (White \& McKenzie
1989). Some hybrid models combine aspects of both passive and active models; the forces that drive plate motions place the continents under tension when subduction is taking place on both sides of the continent, but it is the arrival of a new plume that weakens them and causes them to split and form a new ocean (Hill 1991; Bott 1992; White 1992). With the initial breakup of Gondwana, many authors suggested that one or more centres of thermal activity responsible for the three Middle Jurassic igneous provinces (Karoo, Ferrar and Chon Aike) were situated in the Weddell Sea sector between South America, southern Africa and Antarctica (Storey \& Kyle 1997; Elliott \& Fleming 2000; Ferris et al. 2000, 2003; Storey et al. 2001). The thermal anomalies may have been responsible for Gondwana breakup by doming of the lithosphere and gravitational collapse, leading to continental rifting (active rifting model; Storey \& Kyle 1997). Storey et al. (2001) also suggested that within a regional anomaly or superplume, three hotspots may have existed: beneath the Mozambique Basin (Discovery hotspot); beneath the Weddell Sea embayment region (Shona hotspot); and beneath the Dufek intrusion in the Pensacola Mountains (Bouvet hotspot). If the Weddell Sea region was the centre of magmatic activity at the time of breakup, then, in the case of the Ferrar province, magma would have been 
transported through dyke or sill complexes for distances in excess of $3000 \mathrm{~km}$ (Fig. 1).

Another intriguing aspect of the geological evolution of the Weddell Sea-South Atlantic region in the Middle Jurassic was the formation of rotated microplates (Dalziel \& Elliot 1982; Mitchell et al. 1986). An Ellsworth microplate, formed at the time of breakup, rotated clockwise more than $90^{\circ}$ and migrated from an original position between South Africa and Antarctica to its present position at the head of the Weddell Sea (Schopf 1969; Grunow et al. 1987). The Falkland Islands, like the Ellsworth Mountains, rotated $180^{\circ}$ from a similar position between African and Antarctica to join South America on the opposite side of the Atlantic. We cannot be sure exactly how and why these microplates and rotations occurred, or why Gondwana should have broken up in this way, but it has been suggested that they were in some way linked to the formation of the volcanic province at the start of rifting and the presence of a thermal anomaly or anomalies beneath the Weddell Sea sector of Gondwana, with the microplates forming on a thermal dome of the lithosphere and rotating to their present positions during sea floor spreading (Storey 1995; Storey et al. 2001). Martin (2007) provides an alternative explanation for Gondwana breakup via what he terms double-saloon-door rifting and seafloor spreading in a backarc basin during subduction rollback.

Interestingly, displaced microplates are also a significant component of the final separation of South America from the Antarctic Peninsula and the opening of Drake Passage in the Scotia Sea region: the South Georgia block has moved from a position much closer to southern South America to its present position; the South Orkney block separated from the northern tip of the peninsula to form the Powell Basin; and the South Shetland Islands has separated from the peninsula by sea floor spreading in Bransfield Strait. Although the driving mechanisms may not always be the same, the history of rotated microplates has been repeated in the South Atlantic region and raises intriguing questions about breakup processes.

\subsection{Plume capture}

Various other models involving mantle plumes have also been produced, most notably a plume capture model (Dalziel et al. 2000) where a mantle plume located beneath oceanic lithosphere was subducted along the active margin of Gondwana in the Permo-Triassic forming the Gondwanian fold belt, heating the Gondwana continental lithosphere, ultimately leading to rifting, emplacement of LIPs and sea floor spreading. This model for the first time successfully linked the Gondwanian fold belt with the locus of rifting and the formation of the LIPs of the Karoo. It is based on a long-lived mantle plume derived from a deep-seated thermal anomaly in the mantle, unrelated to the insulation of continental lithosphere.

\subsection{Supercontinental cycles}

There is a growing consensus that supercontinent assembly and breakup is a self-organising process (e.g. Vaughan \& Storey 2007; Gutierrez-Alonso et al. 2008), largely driven by the expansion and contraction of convection cell systems in the upper mantle as their thermal evolution interacts with an overlying supercontinent and its surrounding ocean (e.g. Yoshida \& Santosh 2011), or triggers deep-sourced mantle plumes (e.g. Vaughan \& Storey 2007). Various models exist for modification and evolution of upper mantle convection as a result of thermal insulation by thick continental lithosphere (Anderson 1982; Trubitsyn et al. 2008; Heron \& Lowman 2010), which can ultimately drive supercontinent fragmentation. However, recent modelling studies (Heron \& Lowman 2011) indicate that supercontinent evolution is insufficient to change upper mantle temperatures on the timescale of supercontinent assembly, and that large subcontinental mantle plumes develop as a result of subduction patterns rather than thermal insulation by supercontinents. Modelling of large low shear velocity provinces also confirms this result (Tan et al. 2011). Although the original thermal blanketing idea of Anderson (1982) was conceived prior to mantle plume theories of continental break-up (e.g. White \& McKenzie 1989; Storey 1995), it has been reconciled in part with mantle plume-related mechanisms by Condie et al. (2002) and Condie (2004) via a form of the superplume event concept of Larson (1991a, b; Condie et al. 2001). Convection-based models can also explain supercontinent creation by providing a convergent force, driven by large scale downflow driven by subduction that draws continental fragments together (e.g. Yoshida \& Santosh 2011).

Despite the focus on upper mantle processes as the main driver for the supercontinent cycle, geological evidence suggests that lower mantle processes, hot rising plumes from the core-mantle boundary in particular, are also important (e.g. Vaughan \& Livermore 2005). Upper mantle convection-driven models indicate that supercontinent formation should occur by process of "extroversion" (Murphy et al. 2009). "Extroversion" is a process of supercontinent formation that conforms to models of thermal insulation of the mantle beneath a supercontinent changing upper mantle convection (e.g. Trubitsyn et al. 2008) and driving initial supercontinent fragmentation and formation of a young internal ocean. Supercontinent fragmentation and breakup then proceeds by expansion of the internal ocean and subduction of the thermally older and colder external ocean, ultimately resulting in the formation of a new supercontinent as this ocean closes (Murphy et al. 2009). In the process of "extroversion" supercontinents turn themselves inside out (Murphy \& Nance 2005).

Gondwana breakup conforms to the "extroversion" model, with the supercontinent breaking up by formation of young internal oceans, such as the Indian and South Atlantic oceans, and consumption of exterior oceans, such as neo-Tethys or the Pacific Ocean outboard of New Zealand. The involvement of deep-sourced mantle heat in the breakup of Gondwana remains a subject of discussion (e.g. Eagles \& Konig 2008; Heinonen et al. 2010), although the demonstrated coincidence between the centres of Gondwana large igneous provinces and the margins of the African LLSVP (Fig. 6) argues strongly in favour of it. Geological evidence indicates that mantle plumes were responsible for the large volumes of basaltic and silicic magmatism that erupted during the onset of breakup (e.g. Riley et al. 2003b). Recent plate kinematic analyses, however, suggest that breakup may not have been totally dependent on mantle plumes (Eagles \& Konig 2008; Eagles \& Vaughan 2009).

\section{Environmental impacts}

Increasing evidence links the formation of large igneous provinces with climate change, environmental effects and extinction events throughout the Phanerozoic (Wignall 2001, 2005). In general, LIP eruptions are temporally associated with some or all of the following climatic/environmental effects: phases of rapid global warming/cooling; changes in $\mathrm{pCO}_{2}$ and other atmospheric trace gases $\left(\mathrm{CH}_{4}, \mathrm{SO}_{2}\right.$, halogens); changes in the hydrological cycle; sea-level change (Wignall \& Bond 2008); oceanic anoxia and/or increased oceanic fertilisation; calcification crises; mass extinction/evolutionary radiations; and release of gas hydrates (as interpreted from rapid negative shifts of $\left.\delta^{13} \mathrm{C}\right)$. Although many mechanisms have been proposed to explain these associations, no simple relationship has yet been identified. However, Sobolev et al. (2011) have demonstrated 
a strong relationship between the lethality of a LIP and the volume of recycled oceanic crust in the plume head.

Superplume events (Larson 1991a) cause fundamental reorganisations of Earth surface processes, inferred to be triggered by changes in mantle convection. They are multi-million-year periods characterised by globally high sea levels, increased seafloor spreading rate, plate reorganisation, eruption of $>100,000$ $\mathrm{km}^{2}$ basalt plateaux, and reduced reversal rate frequency of the geomagnetic field (in some cases creating so-called magnetically "quiet zones" in oceanic crust). Superplumes are associated with elevated levels of atmospheric carbon dioxide, increased temperature and major perturbations of the global carbon cycle, with deposition of huge accumulations of carbon-rich sediments (e.g. chalk, coal, oil source rocks) (Larson 1991b). In the case of the best-known superplume event, which happened in the mid-Cretaceous ( $\sim 120-80$ million years ago), the range of effects also includes: ocean margin deformation (Vaughan 1995; Vaughan \& Livermore 2005); widespread emplacement of diamondiferous kimberlites (Larson \& Kincaid 1996; Haggerty 1999); marine anoxia (e.g. Larson \& Erba 1999); and a substantial evolutionary radiation of both marine and terrestrial taxa (Vermeij 1995; Benton 1996; Lupia 1999; Leckie et al. 2002).

The link between the Karoo-Ferrar eruptions and contemporaneous environmental and climatic changes is well established. Good radiometric dates indicate that the eruptions began in the early Toarcian Stage of the Early Jurassic (Pálfy \& Smith 2000). This coincides with a well-documented, oceanic anoxic event, a warming trend, a calcification crisis in equatorial latitudes and marine mass extinction (Wignall 2001; Erba 2004). Examination of carbon isotopes in wood from this time indicate major carbon isotope perturbations, including a sharp negative excursion roughly coincident with the onset of ocean anoxia that is interpreted as the product of a catastrophic release of methane from gas hydrate reservoirs from marine continental margin reservoirs (Hesselbo et al. 2000; Beerling \& Royer 2002; Jenkyns 2003). At the peak warming, the increase of continental weathering rates, probably associated with a change in the hydrological cycle, appears to have been reflected by a decline in ${ }^{187} \mathrm{Os} /{ }^{188} \mathrm{Os}$ ratios (Cohen et al. 2004). The environmental changes are generally connected to volcanic $\mathrm{CO}_{2}$ emissions. $\mathrm{CO}_{2}$ levels and, probably atmospheric temperatures, were also substantially elevated across the boundaries of the Triassic-Jurassic (Beerling \& Royer 2002) and Pliensbachian-Toarcian (Hesselbo et al. 2000), and also in the early Middle Jurassic (174-170 Ma: Hesselbo et al. 2003). Stable isotope analyses of pedogenic carbonates interbedded with the Triassic-Jurassic Central Atlantic Magmatic Province lavas in the Newark Basin show a doubling of pCO to from $2000 \mathrm{ppm}$ to $4400 \mathrm{ppm}$ immediately after the first volcanic unit, with a steady decrease towards pre-eruptive levels over the subsequent 300,000 years (Schaller et al. 2011). This pattern is also observed following the second and third flow units, providing strong support for direct perturbation of atmospheric $\mathrm{CO}_{2}$ levels by large igneous province related volcanism.

The mid-Cretaceous, the time of emplacement of the Marie Byrd Land igneous province (Cenomanian-Turonian, C-T boundary) is marked by the type example of the Cretaceous oceanic anoxic events, the culmination of Cretaceous greenhouse warming (and sea-level rise), and a minor extinction event in the marine fossil record (Hallam \& Wignall 1999; Jenkyns 1999). It thus has many of the hallmarks of other volcanogenic events, although evidence for gas hydrate release is lacking and there is only weak evidence for a calcification crisis (Erba 2004). All of these events essentially coincide with the eruption of the main phase of the Caribbean-Colombian LIP and part of the Kerguelen LIP, and the Madagascan flood basalts (Kerr 1998; Courtillot \& Renne 2003). The oceanic anoxic event OAE 2 itself provides the most obvious cause of the marine extinctions, and the contribution of volcanism to global warming and fertilisation of the oceans provides a route to link volcanism and extinctions (Sinton \& Duncan 1997). Both warming (directly by the oceanic lavas) and possible oceanic acidification would have released $\mathrm{CO}_{2}$ to the atmosphere, thus exacerbating an already established trend of global warming (Kerr 1998, 2005).

The preponderance of evidence for warming strongly suggests that volcanic carbon dioxide emissions were responsible for the initial environmental changes, with knock-on effects that include the release of gas hydrates, acidification of ocean surface waters and elevation of the oceanic calcite compensation depth (CCD). There is also growing evidence that abundant carbonatites are released with LIPs (Ernst \& Bell 2010), providing a mantle source of $\mathrm{CO}_{2}$. The volcanic $\mathrm{CO}_{2}$ eruptions may also have served as a trigger for events such as the release of methane from clathrates. However, the evidence for methane release (the rapid negative shifts of $\delta^{13} \mathrm{C}$ ) is seen much less frequently than the evidence for warming. It appears LIP formation can cause changes that range from the relatively benign (Palaeocene-Eocene boundary), to severely damaging (Toarcian) to utterly catastrophic (end-Permian). Factors such as the degree of explosive magmatism (Elliot \& Hanson 2001; Ross et al. 2005), whether or not large igneous provinces are erupted on the continent or in submarine settings, pre-eruption atmospheric $\mathrm{CO}_{2}$ levels, the proportion of recycled oceanic crust in the plume head (Sobolev et al. 2011), and the rate of eruption, may turn out to be key variables in any environmental changes resulting from volcanic eruptions.

\section{Concluding remarks}

It is very unlikely that a single model can explain the igneous provinces in the Mesozoic and Cenozoic history of Antarctica. However, there seems little doubt, based on the presence of ferropicrites in Dronning Maud Land (DML) and the recent discovery of LLSVPs, that a thermal anomaly was responsible for the DML-Karoo large igneous province, and early Cretaceous large igneous provinces associated with Gondwana breakup. The debate as to whether the anomaly was due to the insulating effect of Gondwana or due to a deep seated mantle plume has largely been resolved by the discovery of LLSVPs, and the evidence they provide for a fixed long-term source for deep seated mantle plumes. The origin of the Ferrar igneous province remains an unresolved issue. It appears likely that the Weddell Sea region, with its volcanic rifted margins, was an important centre of magmatic activity, splitting the Karoo province into an African and Antarctic DML section. However, whether the magmas could have migrated the large distances involved to form the Ferrar province is unproven. A rift along the length of the Transantarctic Mountains driven by changes in plate boundary forces may provide a less dramatic but more compelling case. Similarly, for the Cretaceous Marie Byrd Land province, a link to subduction processes is hard to avoid, although involving the generation of hot rising plumes (Spasojevic et al. 2010). It is also possible that large igneous provinces close to active continental margins may have formed by an indirect connection to slab return flow, which may interact with a hydrated layer in the transition zone to facilitate localised upwellings along active plate margins (Faccenna et al. 2010).

Whatever processes controlled or influenced the breakup of Gondwana, the supercontinent separated into the major continents as we know them today, together with rotated microplates in the Weddell Sea region. We cannot be sure exactly 
how and why these microplates and rotations occurred, or why Gondwana should have broken up in this way, but it may in some way have been linked to the formation of the volcanic provinces at the start of rifting and the presence of a thermal anomaly beneath the Weddell Sea sector of Gondwana, with the microplates forming on a thermal dome of the lithosphere and rotating to their present positions. The trajectory, displacement history and rotation mechanisms of the micro plate component of the Gondwana jigsaw remains a mystery. As is often the case, more than one driver may ultimately be responsible for the disintegration of Gondwana. That some of these processes may be linked in a supercontinent model is also entirely feasible. However, at the present time, the evidence is leaning strongly in favour of a deep mantle origin for hot plumes as the source of the bulk of large igneous province magmatism. Periodic emplacement of LIPs during the Earth's history also coincided with, and possibly had a profound effect on, the environmental and climatic conditions throughout the Earth's history.

\section{Acknowledgements}

We are very grateful to the ISAES organisers for supporting and providing the opportunity to present this review. We are also very grateful to our numerous colleagues that we have worked with on this topic over the years and to the reviewers (Stephen Self, Andrew Kerr and Kathryn Goodenough) for their thorough and detailed reviews that have much improved the manuscript.

\section{References}

Anderson, D. L. 1982. Hotspots, polar wander, Mesozoic convection and the geoid. Nature 297, 391-93.

Anderson, D. L. 2000. The thermal state of the upper mantle: no role for mantle plumes. Geophysical Research Letters 27, 3623-26.

Anderson, D. L. 2005. Large igneous provinces, delamination, and fertile mantle. Elements 1, 271-75.

Antonini, P., Picciirillo, E. M., Petrini, R., Civetta, L., D'Antonio, M. \& Orsi, G. 1999. Enriched mantle-Dupal signature in the genesis of the Jurassic Ferrar tholeiites from Prince Albert Mountains (Victoria Land, Antarctica). Contributions to Mineralogy and Petrology 136, 1-19.

Aragón, E., Rodriguez, A. M. I. \& Benialgo, A. 1996. A caldera field at the Marifil Formation: new volcanogenic interpretation, North Patagonian massif, Argentina. Journal of South American Earth Sciences 9, 321-28.

Beerling, D. J., \& Royer, D. L. 2002. Fossil plants as indicators of the Phanerozoic global carbon cycle. Annual Review of Earth \& Planetary Sciences 30, 527-56.

Behrendt, J. C., LeMasurier, W. E., Cooper, A. K., Tessensohn, F., Tréhu, A. \& Damaske, D. 1991. Geophysical studies of the West Antarctic rift system. Tectonics 10, 1257-73.

Behrendt, J. C., LeMasurier, W. \& Cooper, A. K. 1992. The West Antarctic Rift System - a propagating rift captured by a mantle plume? In Yoshida, K., Kaminuma, K. \& Shiraishi, K. (eds) Recent Progress in Antarctic Earth Science, 315-22, Tokyo: Terra Science.

Benton, M. J. 1996. Testing the roles of competition and expansion in tetrapod evolution. Proceedings of the Royal Society of London, Series B 263(1370), 641-46.

Bott, M. 1992. The styress regime associated with continental breakup. In Storey, B. C., Alabaster, T. \& Pankhurst, R. J. (eds) Magmatism and the Causes of Continental Break-up. Geological Society, London, Special Publication 68, 125-36. Bath, UK: the Geological Society Publishing House.

Brewer, T. S., Hergt, J. M., Hawkesworth, C. J., Rex, D. \& Storey, B. C. 1992. Coats Land dolerites and the generation of Antarctic continental flood basalts. In Storey, B. C., Alabaster, T. \& Pankhurst, R. J. (eds) Magmatism and the Causes of Continental Break-up. Geological Society, London, Special Publication 68, 185-208. Bath, UK: the Geological Society Publishing House.

Bryan, S. E., Riley T. R., Jerram, D. A., Stephens, D. J. \& Leat, P. T. 2002. Silicic volcanism: an undervalued component of large igneous provinces and volcanic rifted margins. Geological Society of America Special Paper 362, 97-118.
Bryan, S. E., Peate, I. U., Peate, D. W., Self, S., Jerram, D. A., Mawby, M. R., Marsh, J. S. \& Miller, J. A. 2010. The largest volcanic eruptions on Earth. Earth-Science Reviews 102(3-4), 207-29.

Burke, K., Steinberger, B., Torsvik, T. H. \& Smethurst, M. A. 2008. Plume Generation Zones at the margins of Large Low Shear Velocity Provinces on the core-mantle boundary. Earth and Planetary Science Letters 265, 49-60.

Caldeira, K. G. \& Rampino, M. R. 1990. Deccan volcanism, greenhouse warming, and the Cretaceous Tertiary boundary. In Sharpton, V. L. \& Ward, P. D. (eds) Global Catastrophes in Earth History. Geological Society of America Special Paper 247, 117-23.

Coltice, N., Phillips, B. R., Bertrand, H., Ricard, Y. \& Rey, P. 2007. Global warming of the mantle at the origin of flood basalts over supercontinents. Geology 35, 391-94.

Coltice, N., Bertrand, H., Rey, P., Jourdan, F., Phillips, B. R. \& Ricard, Y. 2009. Global warming of the mantle beneath continents back to the Archaean. Gondwana Research 15, 254-66.

Cohen, A. S., Coe, A. L., Harding, S. M. \& Schwark, L. 2004. Osmium isotope evidence for the regulation of atmospheric $\mathrm{CO}_{2}$ by continental weathering. Geology 32(2), 157-60.

Condie, K. C. 2004. Supercontinents and superplume events: distinguishing signals in the geologic record. Physics of the Earth and Planetary Interiors 146(1-2), 319-32.

Condie, K. C., Marais, D. J. D. \& Abbott, D. 2001. Precambrian superplumes and supercontinents: a record in black shales, carbon isotopes, and paleoclimates? Precambrian Research 106(3-4), 23960.

Condie, K. C., Abbott, D. \& Des Marais, D. J. 2002. Superplume events in Earth history: causes and effects - preface. Journal of Geodynamics 34(2), 159-62.

Conrad, C. P. \& Gurnis, M. 2003. Seismic tomography, surface uplift, and the breakup of Gondwanaland: Integrating mantle convection backwards in time. Geochemistry, Geophysics, Geosystems 4(3), 1031

Courtillot, V.\& Renne, P. R. 2003. On the ages of flood basalt events. Compte Rendus - Académie des Sciences 335, 113-40.

Cox, K. G. 1988. The Karoo province. In MacDougall, J. D. (ed.) Continental Flood Basalts, 239-71, Dordrecht: Kluwer Academic Publishers.

Cox, K. G. 1992. Karoo igneous activity, and the early stages of the break-up of Gondwanaland. In Storey, B. C., Alabaster, T. \& Pankhurst, R. J. (eds) Magmatism and the Causes of Continental Break-up. Geological Society, London, Special Publication 68, 137-48. Bath, UK: Geological Society Publishing House.

Curtis, M. L., Riley, T. R., Owens, W. H., Leat, P. T. \& Duncan, R. A. 2008. The form, distribution and anisotropy of magnetic susceptibility of Jurassic dykes in H. U. Sverdrupfjella, Dronning Maud Land, Antarctica. Implications for dyke swarm emplacement. Journal of Structural Geology 30, 1429-47.

Dalziel, I. W. D., De Wit, M. J. \& Palmer, K. F. 1974. Fossil marginal basin in the southern Andes. Nature 250(5464), 291-94.

Dalziel, I. W. D., Lawver, L. A. \& Murphy, J. B. 2000. Plumes, orogenesis, and supercontinental fragmentation. Earth and Planetary Science Letters 178(1-2), 1-11.

Dalziel, I. W. D. \& Elliot. D. H. 1982. West Antarctica: Problem child of Antarctica. Tectonics 1, 3-19.

Davies, H. J. \& Bunge, H. P. 2006. Are splash plumes the origin of minor hotspots? Geology 34, 349-52.

Davis, J. M., Elston, W. E. \& Hawkesworth, C. J. 1993. Basic and intermediate volcanism of the Mogollon-Datil volcanic field: implications for mid-Tertiary tectonic transitions in southwestern New Mexico, USA. In Prichard, H. M., Alabaster, T., Harris, N. B. W. \& Neary, C. R. (eds) Magmatic processes and plate tectonics. Geological Society, London, Special Publication 76, 469-88. Bath, UK: Geological Society Publishing House.

Eagles, G. \& Konig, M. 2008. A model of plate kinematics in Gondwana breakup. Geophysical Journal International 173(2), 703-17.

Eagles, G. \& Vaughan, A. P. M. 2009. Gondwana breakup and plate kinematics: Business as usual. Geophysical Research Letters 36(10). DOI: $1029 / 2009 \mathrm{gl037552.}$

Elkins-Tanton, L. T. 2005. Continental magmatism caused by lithospheric delamination. In Foulger, R., Natland, J. H., Presnall, D. C. \& Anderson, D. L. (eds) Plates, Plumes and Paradigms. Geological Society of America, Special Publications 388, 449-61.

Ellam, R. M., Carlson, R. W. \& Shirley, S. B. 1992. Evidence from $\mathrm{Re}-\mathrm{Os}$ isotopes for plume-lithosphere mixing in Karoo flood basalt genesis. Nature 359, 718-21.

Elliot, D. H., Fleming, T. H., Kyle, P. R. \& Foland, K. A. 1999. Long-distance transport of magmas in the Jurassic Ferrar large igneous province, Antarctica. Earth and Planetary Science Letters 167, 89-104. 
Elliot, D. H. \& Fleming, T. H. 2000. Weddell triple junction: the principal focus of Ferrar and Karoo magmatism during initial breakup of Gondwana. Geology 28, 539-42.

Elliot, D. H. \& Fleming, T. H. 2004. Occurrence and dispersal of magmas in the Jurassic Ferrar large igneous province, Antarctica. Gondwana Research 7, 223-37.

Elliot, D. H. \& Hanson, R. E. 2001. Origin of widespread, exceptionally thick basaltic phreatomagmatic tuff breccia in the Middle Jurassic Prebble and Mawson Formations, Antarctica. Journal of Volcanology and Geothermal Research 111(1-4), 183-201.

Encarnación, J., Fleming, T. H., Elliot, D. H. \& Eales, H. V. 1996. Synchronous emplacement of Ferrar and Karoo dolerites and the early breakup of Gondwana. Geology 24, 535-38.

Erba, E. 2004. Calcareous nannofossils and Mesozoic oceanic anoxic events. Marine Micropaleontology 52(1-4), 85-106.

Erlank, A. J. 1984. Petrogenesis of the Volcanic Rocks of the Karoo Province. Geological Society of South Africa, Special Publications 13. Johannesburg: Geological Society of South Africa.

Faccenna, C., Becker, T. W., Lallemandc, S., Lagabriellec, Y. Funiciellod, F. \& Piromallo, C. 2010. Subduction-triggered magmatic pulses: A new class of plumes? Earth and Planetary Science Letters 299, 54-68.

Faccenna, C. \& Becker, T. W. 2010. Shaping mobile belt from small scale convection. Nature $\mathbf{4 6 5}, 602-05$.

Faure, G., Bowman, J. R., Elliot, D. H. \& Jones, L. M. 1974. Strontium isotope composition and petrogenesis of the Kirkpatrick Basalt, Queen Alexandra Range, Antarctica. Contributions to Mineralogy and Petrology 48, 153-69.

Féraud, G., Alric, V., Fornari, M., Bertrand, H. \& Haller, M. 1999. ${ }^{40} \mathrm{Ar} /{ }^{39} \mathrm{Ar}$ dating of the Jurassic volcanic province of Patagonia migrating magmatism relating to Gondwana break-up and subduction. Earth and Planetary Science Letters 172, 83-96.

Ferraccioli, F., Coren, F., Bozzo, E., Zanolla, C., Gandolfi, S., Tabacco, I. \& Frezzotti, M. 2001. Rifted(?) crust at the East Antarctic Craton margin: gravity and magnetic interpretation along a traverse across the Wilkes Subglacial Basin region. Earth and Planetary Science Letters 192(3), 407-21.

Ferris, J., Johnson, A. \& Storey, B. C. 1998. Form and extent of the Dufek intrusion, Antarctica, from newly compiled aeromagnetic data. Earth and Planetary Science Letters 154, 185-202.

Ferris, J., Vaughan, A. P. M. \& Storey, B. C. 2000. Relics of a complex triple junction in the Weddell Sea embayment, Antarctica. Earth and Planetary Science Letters 178, 215-30.

Ferris, J., Storey, B. C., Vaughan, A. P. M., Kyle, P. R. \& Jones, P. C. 2003. The Dufek and Forrestal intrusions, Antarctica: A centre for Ferrar large igneaous province dyke emplacement. Geophysical Research letters 30(6), 81.1-81.4.

Finn, C. A., Muller, R. D. \& Panter, K. S. 2005. A Cenozoic diffuse alkaline magmatic province (DAMP) in the southwest Pacific without rift or plume origin. Geochemistry, Geophysics, Geosystems 6(2). DOI: 10.1029/2004GC000723.

Fitton, J. G., James, D., Kempton, P. D., Ormerod, D. S. \& Leeman, W. P. 1988. Role of lithospheric mantle in the generation of Late Cenozoic basic magmas in the western U.S. In Menzies, M. A. \& Cox, K. G. (eds) Oceanic and continental lithosphere: Similarities and differences. Journal of Petrology Special Volume (1) 331-49.

Fleming, T. H., Elliot, D. H., Jones, J. M., Bowman, J. R. \& Siders, M. A. 1992. Chemical and isotopic variations in an iron-rich flow from the Kirkpatrick Basalt, north Victoria Land, Antarctica: implication for low-temperature alteration. Contributions to Mineralogy and Petrology 73, 105-17.

Foulger, G. R. 2007. The "plate" model for the genesis of melting anomalies. In Foulger G. R. \& Jurdy, D. M. (eds) Plates, Plumes, and Planetary Processes. Geological Society of America, Special Paper 430, 1-28.

Foulger, G. R., Natland, J. H., Presnall, D. C. \& Anderson, D. L. 2005. (eds) Plates, Plumes and Paradigms. Geological Society of America, Special Publication 388. 881 pp.

Ghosh, A. \& Holt, W. E. 2012. Plate motions and stresses from global dynamic models. Science 335(6070), 838-43.

Gibson, S. A., Thompson, R. N. \& Dickin, A. P. 2000. Ferropicrites: geochemical evidence forFe-rich streaks in upwelling mantle plumes. Earth and Planetary Science Letters 174, 355-74.

Grunow, A. M., Kent, D. V. \& Dalziel, I. W. D. 1987. Evolution of the Weddell Sea basin: New palaeomagnetic constraints. Earth Planetary Science Letters 86, 16-26.

Gurnis, M. 1988. Large-scale mantle convection and the aggregation and dispersal of supercontinents. Nature 332, 695-99.

Gutierrez-Alonso, G., Fernandez-Suarez, J., Weil, A. B., Murphy, J. B., Nance, R. D., Corfu, F. \& Johnston, S. T. 2008. Self-subduction of the Pangaean global plate. Nature Geoscience 1(8), 549-53.
Haggerty, S. E. 1999. Earth and planetary sciences - A diamond trilogy: Superplumes, supercontinents and supernovae. Science 285(5429), 851-60.

Hallam, A. \& Wignall, P. B. 1999. Mass extinctions and sea-level changes. Earth-Science Reviews 48(4), 217-50.

Hart, S. R., Hauri, E. H., Oschmann, L. A. \& Whitehead, J. A. 1992. Mantle plumes and entrainment: Isotopic evidence. Science 256(5056), 517-20.

Hart, S. R., Blusztajn, J. \& Craddock, C. 1995. Cenozoic volcanism in Antarctica: Jones Mountains and Peter I Island, Geochimica et Cosmochimica Acta 59(16), 3379-88.

Hart, S. R., Blusztajn, J., LeMasurier, W. E., Rex, W. C., Hawkesworth, C. E. \& Arndt, N. T. E. 1997. Hobbs Coast Cenozoic volcanism: Implications for the West Antarctic rift system, Chemical Geology 139(1-4), 223-48.

Heimann, A., Fleming, T. H., Elliot, D. H. \& Foland, K. A. 1994 A short interval of Jurassic continental flood basalt volcanism in Antarctica as demonstrated by ${ }^{40} \mathrm{Ar} /{ }^{39} \mathrm{Ar}$ geochronology. Earth and Planetary Science Letters 121, 19-41.

Heinonen, J. S., Carlson, R. W. \& Luttinen, A. V. 2010. Isotopic ( $\mathrm{Sr}, \mathrm{Nd}, \mathrm{Pb}$, and $\mathrm{Os}$ ) composition of highly magnesian dikes of Vestfjella, western Dronning Maud Land, Antarctica: A key to the origins of the Jurassic Karoo large igneous province? Chemical Geology 277(3-4), 227-44.

Heinonen, J. S. \& Luttinen, A. V. 2008. Jurassic dikes of Vestfjella, western Dronning Maud Land, Antarctica: geochemical tracing of ferropicrite sources. Lithos 105, 347-64.

Heinonen, J. S. \& Luttinen, A. V. 2010. Mineral chemical evidence for extremely magnesian subalkaline melts from the Antarctic extension of the Karoo large igneous province. Mineralogy and Petrology 99, 201-17.

Hergt, J. M. 2000. Comment on: "Enriched mantle - Dupal signature in the genesis of the Jurassic Ferrar tholeiites from Prince Albert Mountains (Victoria Land, Antarctica)" by Antonini et al. (Contributions to Mineralogy and Petrology 136, 1-19). Contributions to Mineralogy and Petrology 139, 240-44.

Hergt, J. M., Chappell, B. W., McCullagh, M. T., McDougall, I. \& Chivas, T. R. 1989a. Geochemical and isotopic constraints on the origin of the Jurassic dolerites of Tasmania. Journal of Petrology 30, $841-83$.

Hergt, J. M., Chappell, B. W., Faure, G. \& Mensing T. M. 1989b The geochemistry of Jurassic dolerite from Portal Peak, Antarctica. Contributions to Mineralogy and Petrology 102, 298-305.

Hergt, J. M., Peate, D. W. \& Hawkesworth, C. J. 1991. The petrogenesis of Mesozoic Gondwana low-Ti flood basalts. Earth and Planetary Science Letters 105, 134-48.

Heron, P. J. \& Lowman, J. P. 2010. Thermal response of the mantle following the formation of a "super-plate". Geophysical Research Letters 37, L22302.

Heron, P. J. \& Lowman, J. P. 2011. The effects of supercontinent size and thermal insulation on the formation of mantle plumes. Tectonophysics 510(1-2), 28-38.

Hesselbo, S. P., Grocke, D. R., Jenkyns, H. C., Bjerrum, C. J., Farrimond, P., Bell, H. S. M. \& Green, O. R. 2000. Massive dissociation of gas hydrate during a Jurassic oceanic anoxic event. Nature 406(6794), 392-95

Hesselbo, S. P., Morgans-Bell, H. S., McElwain, J. C., Rees, P. M., Robinson, S. A. \& Ross, C. E. 2003. Carbon-cycle perturbation in the Middle Jurassic and accompanying changes in the terrestrial paleoenvironment. Journal of Geology 111(3), 259-76.

Hill, R. I. 1991. Starting plumes and continental break-up. Earth and Planetary Science Letters 104, 398-416.

Hofmann A. W. 1997. Mantle geochemistry: a message from oceanic volcanism. Nature 385, 219-29.

Hofmann, A. W. \& White, W. M. 1982. Mantle plumes from ancient continental crust. Earth and Planetary Science Letters 57, 42136.

Hole, M. J. \& LeMasurier, W. E., 1994. Tectonic controls on the geochemical composition of Cenozoic mafic alkaline volcanic rock from West Antarctica. Contributions to Mineralogy and Petrology 117, 187-202.

Huppert, H. E. \& Sparks, R. S. J. 1988. The generation of granitic magmas by intrusion of basalt into continental crust. Journal of Petrology 29, 599-624.

Jenkyns H. C. 1999. Mesozoic anoxic events and palaeoclimate. Zentralblatt für Geologie und Palaontologie, Teil 1: Allgemeine, Angewandte, Regionale und Historische Geologie, 7-9.

Jenkyns, H. C. 2003. Evidence for rapid climate change in the Mesozoic-Palaeogene greenhouse world. Philosophical Transactions of the Royal Society, London, Series A 361(1810), 1885916. 
Johnston, S. T. \& Thorkelson, D. J. 2000. Continental flood basalts: episodic magmatism above long-lived hotspots. Earth and Planetary Science Letters 175, 247-56.

Kerr, A. C. 1998. Oceanic plateau formation: a cause of mass extinction and black shale deposition around the CenomanianTuronian boundary? Journal of the Geological Society, London 155(2), 619-26.

Kerr, A. C. 2005. Oceanic LIPs: The kiss of death. Elements 1(5), 289-92.

Kerr, A. C., Saunders, A. D., Tarney, J., Berry, N. H. \& Hards, V. L. 1995. Depleted mantle-plume geochemical signature: no paradox for plume theories. Geology 23, 843-46.

King, S. D. \& Anderson, D. L. 1995. An alternative mechanism of flood basalt formation. Earth and Planetary Science Letters 136, 269-79.

King, S. D. \& Ritsema, J. 2000. African hot spot volcanism: Smallscale convection in the upper mantle beneath cratons. Science 290, 1137-40.

Kuroda, J., Ogawa, N. O., Tanimizu, M., Coffin, M. F., Tokuyama, H., Kitazato, H. \& Ohkouchi, N. 2007. Contemporaneous massive subaerial volcanism and late cretaceous Oceanic Anoxic Event 2. Earth and Planetary Science Letters 256(1-2), 211-23.

Kyle, P. R. 1980. Development of heterogeneities in the subcontinental mantle: evidence from the Ferrar Group, Antarctica. Contributions to Mineralogy and Petrology 73, 89-104.

Kyle P. R., Elliot, D. H. \& Sutter, J. F. 1981. Jurassic Ferrar Supergroup tholeiites from the Transantarctic Mountains, Antarctica, and their relation to the initial fragmentation of Gondwana. In Cresswall, M. M. \& Vella, P. (eds) Gondwana Five: Proceedings of the Fifth Gondwana Symposium, Wellington, New Zealand, 283-87. Rotterdam: A. A. Balkema.

Kyle P. R., Pankhurst, R. J. \& Bowman, J. R. 1983. Isotopic and chemical variations in Kirkpatrick Basalt Group rocks from southern Victoria Land, In Oliver, R. L., James, P. R. \& Jago, J. (eds) Antarctic Earth Science, 234-37. Canberra: Australian Academy of Science.

Kyle, P. R., Pankhurst, R., Mukasa, S., Panter, K., Smellie, J. \& McIntosh, W. 1994. Sr, $\mathrm{Nd}$ and $\mathrm{Pb}$ isotopic variations in the Marie Byrd Plume, West Antarctica. U.S. Geological. Survey Circular 1107, 184.

Lanyon, R., Varne, R. \& Crawford, A. J. 1993. Tasmanian Tertiary basalts, the Balleny Plume, and opening of the Tasman Sea southwest Pacific Ocean. Geology 21, 555-58.

Larson, R. L. 1991a. Geological consequences of superplumes. Geology 19(10), 963-66.

Larson, R. L. 1991b. Latest pulse of Earth: evidence for a midCretaceous superplume. Geology 19(6), 547-50.

Larson, R. L. \& Erba, E. 1999. Onset of the mid-Cretaceous greenhouse in the Barremian-Aptian: igneous events and the biological, sedimentary, and geochemical responses. Paleoceanography 14(6), $663-78$.

Larson, R. L. \& Kincaid, C. 1996. Onset of mid-Cretaceous volcanism by elevation of the $670 \mathrm{~km}$ thermal boundary layer. Geology 24(6), 551-54

Leahy, G. M. \& Bercovici, D. 2007. On the dynamics of a hydrous melt layer above the transition zone. Journal of Geophysical Research 112, B07401.

Leat, P. T. 2008. On the long-distance transport of Ferrar magmas. Geological Society, London, Special Publication 302, 45-61.

Leat, P. T., Riley, T. R., Storey, B. C., Kelley, S. P. \& Millar, I. L. 2000. Middle Jurassic ultramafic lamprophyre dykes within the Ferrar magmatic province, Pensacola Mountains, Antarctica. Mineralogical Magazine 64, 95-111.

Leckie, R. M., Bralower, T. J. \& Cashman, R. 2002. Oceanic anoxic events and plankton evolution: biotic response to tectonic forcing during the mid-Cretaceous. Paleoceanography 17(3), 1-12.

LeMasurier, W. E. 1990. Late Cenozoic volcanism on the Antarctic Plate: an overview. In LeMasurier, W. E. \& Thomson, J. W. (eds) Volcanoes of the Antarctic Plate and Southern Oceans. Antarctic Research Series 48, 1-18. Washington, DC: American Geophysical Union.

LeMasurier, W. E. \& Landis, C. A. 1996. Mantle-plume activity recorded by low-relief erosion surfaces in West Antarctica and New Zealand Geological Society of America Bulletin 108(11), 1450-66.

LeMasurier, W. E. \& Rex, D. C. 1989. Evolution of linear volcanic ranges in Marie Byrd Land, West Antarctica. Journal of Geophysical Research 94(6), 7223-36.

LeMasurier, W. E. \& Thomson, J. W. (eds). 1990. Volcanoes of the Antarctic Plate and Southern Oceans. Antarctic Research Series 48. Washington, DC: American Geophysical Union. 487 pp.
Liu, L. J., Tan, Y., Sun, D. Y., Chen, M. \& Helmberger, D. 2011. Trans-Pacific whole mantle structure. Journal of Geophysical Research: Solid Earth 116, B04306.

Lupia, R. 1999. Discordant morphological disparity and taxonomic diversity during the Cretaceous angiosperm radiation: North American pollen record. Paleobiology 25(1), 1-28.

Luttinen, A. V. \& Furnes, H. 2000. Flood basalts of Vestfjella: Jurassic magmatism across an Archaean-Proterozoic lithospheric boundary in Dronning Maud Land, Antarctica. Journal of Petrology 41, 1271-305.

Luyendyk, B. P. 1995. Hypothesis for Cretaceous rifting of East Gondwana caused by subducted slab capture. Geology 23(4), 373-76.

Marzoli, A., Renne, P. R., Piccirillo, E. M., Ernesto, M., Bellieni, G. \& De Min, A. 1999. Extensive 200-million-year-old continental flood basalts of the Central Atlantic Magmatic Province. Science 284, 616-18.

Mikhailov, V., Stephenson, R. \& Diament, M. 2010. Modelling of compression and extension of the continental lithosphere: Towards rehabilitation of the necking-level model. Journal of Geodynamics 50(5), 368-80.

Mitchell, C., Taylor, G. K., Cox, K. G. \& Shaw, J. 1986. Are the Falkland Islands a rotated microplate? Nature 319, 131-34.

Molzahn, M., Reisberg, L. \& Wörner, G. 1996. Os, Sr, Nd, Pb and O isotope and trace element data from the Ferrar flood basalts, Antarctica: evidence for an enriched subcontinental lithospheric source. Earth and Planetary Science Letters 144, 529-46.

Montelli, R., Nolet, G., Dahlen, F. A., Masters, G., Engdahl, E. R. \& Hung, S.-H. 2004. Finite frequency tomography reveals a variety of plumes in the mantle. Science 303(5656), 338-43.

Montelli, R., Nolet, G., Dahlen, F. A. \& Masters, G. 2006. A catalogue of deep mantle plumes: New results from finite-frequency tomography. Geochemistry, Geophysics, Geosystems 7(11). DOI: $10.1029 / 2006 \mathrm{GC} 001248$.

Morgan, W. J. 1971. Convection plumes in lower mantle. Nature 230(5288), 42-43.

Morgan, W. J. 1981. Hotspot tracks and the opening of the Indian and Atlantic Oceans. In Emiliani, C. (ed.) The Oceanic Lithosphere, 443-88. New York: Wiley.

Mortimer, N., Parkinson, D., Raine, J. I., Adams, C. J., Graham, I. J., Oliver, P. J. \& Palmer, K. 1995. Ferrar magmatic province rocks discovered in New Zealand: implications for Mesozoic Gondwana geology. Geology 23, 185-88.

Murphy, J. B., Nance, R. D. \& Cawood, P. A. 2009. Contrasting modes of supercontinent formation and the conundrum of Pangea. Gondwana Research 15(3-4), 408-20.

Murphy, J. B. \& Nance, R. D. 2005. Do supercontinents turn inside-in or inside-out? International Geology Review 47(6), 591-619.

Pálfy, J. \& Smith, P. L. 2000. Synchrony between Early Jurassic extinction, oceanic anoxic event, and the Karoo-Ferrar flood basalt volcanism. Geology 28(8), 747-50.

Pankhurst, R. J., Leat, P. T., Sruoga, P., Rapela, C. W., Márquez, M., Storey, B. C. \& Riley, T. R. 1998. The Chon-Aike silicic igneous province of Patagonia and related rocks in Antarctica: a silicic large igneous province. Journal of Volcanology and Geothermal Research 81, 113-36.

Pankhurst, R. J., Riley, T. R., Fanning, C. M. \& Kelley, S. P. 2000. Episodic silicic volcanism in Patagonia and the Antarctic Peninsula: chronology of magmatism associated with break-up of Gondwana. Journal of Petrology 41, 605-25.

Pankhurst, R. J. \& Rapela, C. R. 1995. Production of Jurassic rhyolites by anatexis of the lower crust of Patagonia. Earth and Planetary Science Letters 134, 23-36.

Pankhurst, R. J. \& Vaughan, A. P. M. 2009. The tectonic context of the Early Palaeozoic southern margin of Gondwana. In Bassett, M. G. (ed.) Early Palaeozoic peri-Gondwana terranes: new insights from tectonics and biogeography. Geological Society, London, Special Publication 325, 169-74.

Panter, K. S., McIntosh, W. C. \& Smellie, J. L. 1994. Volcanic history of Mount Sidley, a major alkaline volcano in Marie Byrd Land, Antarctica. Bulletin of Volcanology 56, 361-76.

Panter, K., Blusztajn, J., Hart, S. R. \& Kyle, P. 1997. Late CretaceousNeogene basalts from Chatham Island: Implications for HIMU mantle beneath continental borderlands of the Southwest Pacific. In Seventh Annual V. M. Goldschmidt Conference, LPI Contribution 921, 156-57. Houston, Texas: Lunar and Planetary Institute.

Panter, K. S., Hart, S. R., Kyle, P., Blusztajn, J. \& Wilch, T. 2000. Geochemistry of Late Cenozoic basalts from the Crary Mountains: Characterization of mantle sources in Marie Byrd Land, Antarctica. Chemical Geology 165, 215-41. 
Pearce, J. A., Harris, N. B. W. \& Tindle, A. G. 1984. Trace elemen discrimination diagrams for the tectonic interpretation of granitic rocks. Journal of Petrology 25, 956-83.

Peate, D. W. 1997. The Parana-Etendeka Province. In Mahoney, J. J. \& Coffin, M. R. (eds) Large igneous provinces: continental, oceanic, and planetary flood volcanism. AGU Geophysical Monograph 100, 217-44. Washington, DC: American Geophysical Union.

Rey, P. F. \& Mueller, R. D. 2010. Fragmentation of active continental plate margins owing to the buoyancy of the mantle wedge. Nature Geoscience 3(4), 257-61.

Richards, M. A., Duncan, R. A. \& Courtillot, V. E. 1989. Flood basalts and hot-spot tracks: plume heads and tails. Science 246(4926), 10307

Riley, T. R., Leat, P. T., Pankhurst, R. J. \& Harris, C. 2001. Origins of large volume rhyolitic volcanism in the Antarctic Peninsula and Patagonia by crustal melting. Journal of Petrology 42, 1043 65

Riley, T. R., Leat, P. T., Kelley, S. P., Millar, I. L \& Thirlwall, M. F. 2003a. Thinning of the Antarctic Peninsula lithosphere through the Mesozoic: evidence from Middle Jurassic basaltic lavas. Lithos 67, 163-79.

Riley, T. R., Leat, P. T., Storey, B. C., Parkinson, I. J. \& Millar, I. L. 2003b. Ultramafic lamprophyres of the Ferrar large igneous province: evidence for a HIMU mantle component. Lithos 66(1-2), 63-76.

Riley, T. R., Millar, I. L., Watkeys, M. K., Curtis, M. L., Leat, P. T. Klausen, M. B. \& Fanning C. M. 2004. U-Pb zircon (SHRIMP) ages for the Lebombo rhyolites, South Africa: refining the duration of Karoo volcanism. Journal of the Geological Society, London 161, 542-45.

Riley, T. R., Leat, P. T., Curtis, M. L., Millar, I. L. \& Fazel, A. 2005. Early-Middle Jurassic dolerite dykes from western Dronning Maud Land (Antarctica): identifying mantle sources in the Karoo large igneous province. Journal of Petrology 46, 1489-524.

Riley, T. R., Curtis, M. L., Leat, P. T., Watkeys, M. K., Duncan, R. A., Millar, L. L. \& Owens, W. H. 2006. Overlap of Karoo and Ferrar magma types in KwaZulu-Natal, South Africa. Journal of Petrology 47, 541-56.

Riley, T. R., Flowerdew, M. J., Hunter, M. A. \& Whitehouse, M. J. 2010. Middle Jurassic rhyolite volcanism of eastern Graham Land, Antarctic Peninsula: age correlations and stratigraphic relationships. Geological Magazine 147(4), 581-95.

Riley, T. R. \& Knight, K. B. 2001. Age of pre-break-up Gondwana magmatism: a review. Antarctic Science 13, 99-110.

Riley, T. R. \& Leat, P. T. 1999. Large volume silicic volcanism along the proto-Pacific margin of Gondwana: lithological and stratigraphcial investigations from the Antarctic Peninsula. Geological Magazine 136, 1-16.

Rocchi, S., Armienti, P., D’Orazio, M., Tonarini, S., Wijbrans, J. R. \& Di Vincenzo, G. 2002. Cenozoic magmatism in the western Ross Embayment: Role of mantle plume versus plate dynamics in the development of the West Antarctic Rift System. Journal of Geophysical Research 107(B9), 2195

Rocchi, S., Storti, F., Di Vincenzo, G. \& Rossetti, F. 2003, Intraplate strike-slip tectonics as an alternative to mantle plume activity for the Cenozoic rift magmatism in the Ross Sea region, Antarctica, in Intraplate Strike-Slip Deformation Belts. In Storti, F., Holdsworth, R. E. \& Salvini, F. (eds) Geological Society, London, Special Publication 210, 145-58.

Rocchi, S., Di Vincenzo, G. \& Armienti, P. 2005. No plume, no rift magmatism in the West Antarctic rift. In Foulger, G. R., Anderson, D. L., Natland, J. H. \& Presnall, D. C. (eds) Plates, Plumes \& Paradigms. Geological Society of America Special Paper $\mathbf{3 8 8}$ 435-47.

Rocholl, A., Stein, M., Molzahn, M., Hart, S. R. \& Worner G. 1995. Geochemical evolution of rift magmas by progressive tapping of a stratified mantle source beneath the Ross Sea Rift, northern Victoria Land, Antarctica. Earth and Planetary Science Letters 131(3-4), 207-24.

Rosenbaum, G., Weinberg, R. F. \& Regenauer-Lieb, K. 2008. The geodynamics of lithospheric extension. Tectonophysics $\mathbf{4 5 8}(1-4)$, $1-8$.

Ross, P. S., Peate, I. U., McClintock, M. K., Xu, Y. G., Skilling, I. P., White, J. D. L. \& Houghton, B. F. 2005. Mafic volcaniclastic deposits in flood basalt provinces: A review. Journal of Volcanology and Geothermal Research 145(3-4), 281-314.

Rowley, P. D., Schmidt, D. L. \& Williams. P. L. 1982. The Mount Poster Formation, southernm Antarctic Peninsula. Antarctic Journal of the United States 17(5), 38-39.

Salvini, F., Brancolini, G., Busetti, M., Storti, G., Mazzarini, F. \& Coren, F. 1997. Cenozoic geodynamics of the Ross Sea region,
Antarctica: crustal extension, intraplate strike-slip faulting, and tectonic inheritance. Journal of Geophysical Research 102(B11), 24,669-96.

Schaller, M. F., Wright, J. D. \& Kent, D. V. 2011. Atmospheric $\mathrm{P}-\mathrm{CO}_{2}$ perturbations associated with the Central Atlantic Magmatic Province. Science 331(6023), 1404-09.

Schmerr, N., Garnero, E. \& McNamara, A. 2010. Deep mantle plumes and convective upwelling beneath the Pacific Ocean. Earth and Planetary Science Letters 294(1-2), 143-51.

Schopf, J. M. 1969. Ellsworth Mountains: position in West Antarctica due to sea floor spreading. Science 164, 63-66.

Self, S., Widdowson, M., Thordarson, T. \& Jay, A. E. 2006. Volatile fluxes during flood basalt eruptions and potential effects on th eglobal environment: A Deccan perspective. Earth and Planetary Science Letters 248, 518-32.

Siddoway, C. 2010. Tectonics: Microplate motion. Nature Geoscience 3(4), 225-26

Sigloch K., McQuarrie, N. \& Nolet, G. 2008. Two-stage subduction history under North America inferred from multiple-frequency tomography. Nature Geoscience 1, 458-62.

Sinton, C. W. \& Duncan, R. A. 1997. Potential links between ocean plateau volcanism and global ocean anoxia at the CenomanianTuronian boundary. Economic Geology 92, 836-42.

Sobolev, S. V., Sobolev, A. V., Kuzmin, D. V., Krivolutskaya, N. A., Petrunin, A. G., Arndt, N. T., Radko, V. A. and Vasiliev, Y. R. 2011. Linking mantle plumes, large igneous provinces and environmental catastrophes. Nature 477, 312-16.

Spasojevic, S., Gurnis, M. \& Sutherland, R. 2010. Inferring mantle properties with an evolving dynamic model of the AntarcticaNew Zealand region from the Late Cretaceous. Journal of Geophysical Research-Solid Earth 115, B05402, 10.1029/2009jb006612.

Steinberger, B. \& Torsvik, T. H. 2012. A geodynamic model of plumes from the margins of Large Low Shear Velocity Provinces. Geochemistry, Geophysics, Geosystems 13(1). DOI: 10.1029/ 2011 GC003808.

Storey, B. C. 1995. The role of mantle plumes in continental breakup: case histories from Gondwanaland. Nature 377(6547), 301-08.

Storey, B. C., Hole, M. J., Pankhurst, R. J., Millar, I. L. \& Vennum, W. R. 1988. Middle Jurassic within-plate granites in West Antarctica and their bearing on the break-up of Gondwanaland. Journal of the Geological Society, London 145, 999-1007.

Storey, B. C., Leat, P. T., Weaver, S. D., Pankhurst, R. J., Bradshaw, J. D. \& Kelley, S. 1999. Mantle plumes and Antarctica-New Zealand rifting: Evidence from Mid-Cretaceous mafic dykes Journal of the Geological Society, London 156(4), 659-71.

Storey, B. C., Leat, P. T. \& Ferris, J. K. 2001. The location of mantleplume centers during the initial stages of Gondwana break-up. In Ernst, R. E. \& Buchan, K. L. (eds) Mantle Plumes: Their identification through time. Geological Society of America Special Papers 352, $71-80$.

Storey, B. C. \& Kyle, P. R. 1997. An active mantle mechanism for Gondwana breakup. South African Journal of Geology 100(4), 283-90.

Stump, E. 1995. The Ross Orogen of the Transantarctic Mountains Cambridge, UK: Cambridge University Press.

Sutherland, R., Spasojevic, S. \& Gurnis, M. 2010. Mantle upwelling after Gondwana subduction death explains anomalous topography and subsidence histories of eastern New Zealand and West Antarctica. Geology 38(2), 155-58.

Sweeney, R. J., Duncan, A. R. \& Erlank, A. J. 1994. Geochemistry and petrogenesis of central Lebombo basalts of the Karoo igneous province. Journal of Petrology 35, 95-125.

Tan, E., Leng, W., Zhong, S. J. \& Gurnis, M. 2011. On the location of plumes and lateral movement of thermochemical structures with high bulk modulus in the 3-D compressible mantle. Geochemistry, Geophysics, Geosystems 12(7). DOI: 10.1029/2011GC003665.

ten Brink, U. S., Bannister, S., Beaudoin, B. C. \& Stern, T. A. 1993. Geophysical investigations of the tectonic boundary between East and West Antarctica. Science 261(5117), 45-50.

Tessensohn, F. \& Wörner, G. 1991. The Ross Sea Rift System, Antarctica: Structure, evolution and analogues. In Thomson, M. R. A., Crame, J. A. \& Thomson, J. W. (eds) Geological evolution of Antarctica, 273-78. New York: Cambridge University Press.

Thompson, R. N. \& Gibson, S. A. 2000. Transient high temperatures in mantle plume heads inferred from magnesian olivines in Phanerozoic picrites. Nature 407, 502-06.

Torsvik, T. H., Smethurst, M. A., Burke, K. \& Steinberger, B. 2008 Long term stability in deep mantle structure: Evidence from the similar to 300 Ma Skagerrak-Centered Large Igneous Province (the SCLIP). Earth and Planetary Science Letters 267(3-4), 44452 . 
Torsvik, T. H., Burke, K., Steinberger, B., Webb, S. J. \& Ashwall, L. D. 2010. Diamonds sampled by plumes from the core-mantle boundary. Nature 466(7304), 352-55.

Tronnes, R. G. 2010. Structure, mineralogy and dynamics of the lowermost mantle. Mineralogy and Petrology 99, 243-61.

Trubitsyn, V. P., Mooney, W. D. \& Abbott, D. H. 2003. Cold cratonic roots and thermal blankets: how continents affect mantle convection. International Geology Review 45(6), 479-96.

van der Hilst, R. D., Widiyantoro, S. \& Engdahl, E. R. 1997. Evidence for deep mantle circulation from global tomography. Nature 386(6625), 578-84.

Vaughan, A. P. M. 1995. Circum-Pacific mid-Cretaceous deformation and uplift: a superplume-related event? Geology 23(6), 491-94.

Vaughan, A. P. M. \& Livermore, R. A. 2005. Episodicity of Mesozoic terrane accretion along the Pacific margin of Gondwana: implications for superplume-plate interactions. In Vaughan, A. P. M., Leat, P. T. \& Pankhurst, R. J. (eds) Terrane Processes at the Margins of Gondwana. Geological Society, London, Special Publication 246, 143-78.

Vaughan, A. P. M. \& Storey, B. C. 2007. A new supercontinent selfdestruct mechanism: evidence from the Late Triassic-Early Jurassic. Journal of the Geological Society, London 164, 383-92.

Vermeij, G. J. 1977. The Mesozoic marine revolution: evidence from snails, predators and grazers. Paleobiology 3, 245-48.

Vermeij, G. J. 1995. Economics, volcanoes, and Phanerozoic revolutions. Paleobiology 21(2), 125-52.

Wang, Y. \& Wen, L. X. 2004. Mapping the geometry and geographic distribution of a very low velocity province at the base of the Earth's mantle. Journal of Geophysical Research-Solid Earth 109(B10), B10305.

West J. D., Fouch, M. J., Roth, J. B. \& Elkins-Tanton, L. T. 2009. Vertical mantle flow associated with a lithospheric drip beneath the Great Basin, Nature Geoscience 2, 439-44.

Weaver, S. D., Storey, B. C., Pankhurst, R. J., Mukasa, S. B., DiVenere, V. J. \& Bradshaw, J. D. 1994. Antarctica-New Zealand rifting and Marie Byrd Land lithospheric magmatism linked to ridge subduction and mantle plume activity. Geology 22, 81114.

Wever, H. E. \& Storey, B. C. 1992. Bimodal magmatism in northest Palmer Land, Antarctic Peninslua: geochemical evidence for a Jurassic ensialic back-arc basin. Tectonophysics 205, 239-59.
White, R. S. 1992. Magmatism during and after continental break-up. In Storey, B. C., Alabaster, T. \& Pankhurst, R. J. (eds) Magmatism and the Causes of Continental Break-up. Geological Society, London, Special Publications 68, 1-16.

White, R. S. \& McKenzie, D. P. 1989. Magmatism at rift zones: the generation of volcanic continental margins and flood basalts. Journal of Geophysical Research-Solid Earth 94(B6), 7685-729.

Wignall, P. B. 2001. Large igneous provinces and mass extinctions. Earth-Science Reviews 53(1-2), 1-33.

Wignall, P. B. 2005. The link between large igneous province eruptions and mass extinctions. In Saunders, A. D. (ed.) Large Igneous Provinces: Origin and Environmental Consequences. Elements 1(5), 293-97. Chantilly, Virginia: the Mineralogical Society of America.

Wignall, P. B., Newton, R. J. \& Little, C. T. S. 2005. The timing of paleoenvironmental change and cause-and-effect relationships during the early Jurassic mass extinction in Europe. American Journal of Science 305(10), 1014-32.

Wignall, P. B. \& Bond, D. P. G. 2008. The end-Triassic and Early Jurassic mass extinction records in the British Isles. Proceedings of the Geologists' Association 119, 73-84.

Wilson, M. \& Downes, H. 2006. Tertiary-Quaternary intra-plate magmatism in Europe and its relationships to mantle dynamics. In Gee, D. \& Stephenson, R. (eds) European Lithosphere Dynamics. Geological Society, London, Memoir 32, 147-66.

Wilson, T. J. 1963. A possible origin of the Hawaiian Islands. Canadian Journal of Physics 41, 863-70.

Wooden, J. L. Czamanske, G. K., Federenko, V. A., Arndt, N. T., Chauvel, C., Bouse, R. M., King, B. W., Knight, R. J. \& Siems, D. F. 1993. Isotopic and trace element constraints on mantle and crustal contributions to Siberian continental flood basalts, Noril'sk area, Siberia. Geochimica et Cosmochimica Acta 57, 3677-704.

Yoshida, M. \& Santosh, M. 2011. Supercontinents, mantle dynamics and plate tectonics: A perspective based on conceptual vs. numerical models. Earth-Science Reviews 105(1-2), 1-24.

Zhu, D. C., Chung, S. L., Mo, X. X., Zhao, Z. D., Niu, Y. L., Song, B. \& Yang, Y. H. 2009. The 132 Ma Comei-Bunbury large igneous province: Remnants identified in present-day southeastern Tibet and southwestern Australia. Geology 37(7), 583-86.

MS received 14 May 2011. Accepted for publication 29 April 2012.
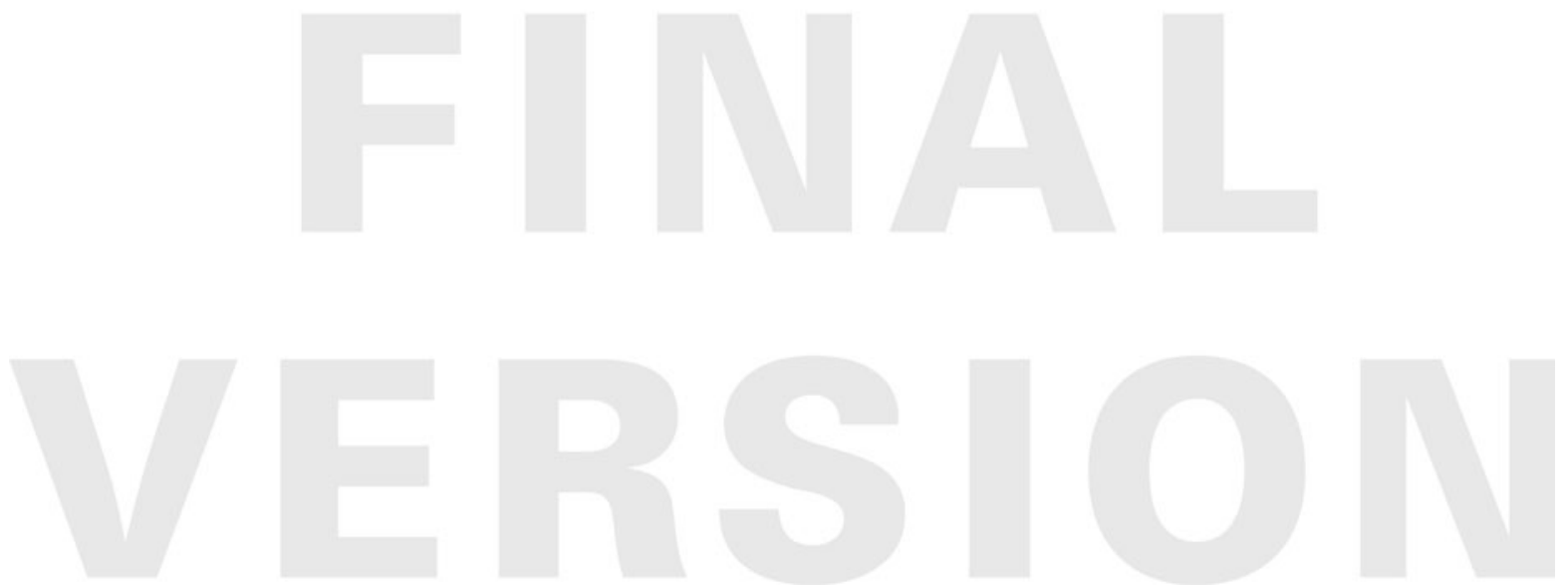